University of Rhode Island

DigitalCommons@URI

Open Access Dissertations

2020

\title{
THE NEW AND THE OLD FOR ENGAGEMENT IN BUSINESS \\ LEARNING: GAMIFIED COURSE DESIGN AND OP-ED WRITING PROJECT
}

Hee Yoon Kwon

University of Rhode Island, hykwon@uri.edu

Follow this and additional works at: https://digitalcommons.uri.edu/oa_diss

\section{Recommended Citation}

Kwon, Hee Yoon, "THE NEW AND THE OLD FOR ENGAGEMENT IN BUSINESS LEARNING: GAMIFIED COURSE DESIGN AND OP-ED WRITING PROJECT" (2020). Open Access Dissertations. Paper 1203. https://digitalcommons.uri.edu/oa_diss/1203

This Dissertation is brought to you for free and open access by DigitalCommons@URI. It has been accepted for inclusion in Open Access Dissertations by an authorized administrator of DigitalCommons@URI. For more information, please contact digitalcommons-group@uri.edu. 
THE NEW AND THE OLD FOR ENGAGEMENT IN BUSINESS LEARNING: GAMIFIED COURSE DESIGN AND OP-ED WRITING PROJECT

BY

HEE YOON KWON

A DISSERTATION SUBMITTED IN PARTIAL FULFILLMENT OF THE

REQUIREMENTS FOR THE DEGREE OF

DOCTOR OF PHILOSOPHY

IN

OPERATIONS AND SUPPLY CHAIN MANAGEMENT

UNIVERSITY OF RHODE ISLAND 


\section{DOCTOR OF PHILOSOPHY DISSERTATION}

OF

HEE YOON KWON

\section{APPROVED:}

Dissertation Committee:

Major Professor Koray Özpolat

Douglas N. Hales

Resit Sendag

Anis Triki

Brenton DeBoef

DEAN OF THE GRADUATE SCHOOL

UNIVERSITY OF RHODE ISLAND

2020 


\begin{abstract}
Achieving higher level of student engagement in learning is a popular topic among educators of various disciplines. Numerous methods have been explored to the end of making learning more engaging and students more motivated and yet, due to the everchanging nature of the "new generation", there always seems to be something new to try. In particular, college students that major in business strive for opportunities to engage in hands-on activities that are relevant in the real-world to be better prepared for their professional careers after graduation.
\end{abstract}

The advancements in computer technology and the rising popularity of videogames as entertainment media consumption gave rise to the study of how the design principles of games can be applied in other activities, such as learning, training, and management. Gamification is widely adopted in the industry for onboarding, training, performance management, and customer engagement. In the academia, gamification studies have grown in higher education in various disciplines such as business, medicine, and engineering. Recent gamification studies grounded in selfdetermination theory (SDT) call for proper gamified design to cast a deeper look into human behavior on what gives us a click in the mind to become engaged and motivated in activities typically viewed as distant from fun and exciting.

The first manuscript, a study in gamified Operations \& Supply Chain Management course design, explores what gamification does to student engagement, satisfaction, and content knowledge when applied restrictively to assessment activities within the course. The negative findings suggest that a wider, more comprehensive 
application is needed for the gamified course to be engaging, as well as lead to improved academic performance.

While exploring what the new technique of gamification can offer to student engagement, it is worth exploring a legacy media with the same goal: newspapers. The popularity of television and internet forced the newspaper industry to adopt online publication as their business model due to diminished demand for print circulation. However, print and online local and regional newspapers still dominate the US market, making them a viable channel of engagement for students.

The second manuscript presents a team project designed to guide students in applying their learning in an opinionated writing and submitting their voice to local and regional newspapers. Designed according to principles of active learning theory and team-based learning theory, the op-ed writing project presents a unique learning opportunity to students by taking what they've learned in the classroom and scaling the abstract constructs and principles down to their own community contexts in the neighborhood, local, regional, or national level, while interacting with teammates for a consensus opinion of their own.

The op-ed writing project led to seven student op-eds published in local and regional newspapers. Survey results show positive student perceptions in realizing their opinion is worth sharing with the public, in learning a new style of writing, and in that the project helped them learn the course materials better, indicating a successful implementation. 


\section{ACKNOWLEDGEMENT}

I am deeply honored, grateful, and humbled to acknowledge those that contributed to my journey. I have met so many brilliant minds and warm hearts along the way that encouraged and inspired me, that it would be impractical to list here the names of each and every one, and unwise to try. For now, let this page be my gratitude spoken for those to whom I cannot say my thanks via means allowed to a mortal. We will meet again.

My Major Professor, Koray Özpolat, has been the embodiment of the passion, patience, and push that brought me here. I have always referred to the Ph.D journey as a Jedi Apprenticeship, and if I ever stand as a Jedi Knight, it is through the guidance, discipline, and teaching of my Jedi Master. I am immensely grateful for his contribution and extremely honored to be his first doctoral student. It's been quite a ride.

My wife and child are the reason I am here now, and they've sacrificed a great deal for me. I thank them both for shaping me into a more responsible man, and showing me the way home. We also stand on the unconditional love and firm support of our parents. 


\section{DEDICATION}

to

\section{HYOJIN AND LUKE DOHYUN}

my cause and effect, my equilibrium; the two centers of my elliptical universe. 


\section{PREFACE}

Please note that this dissertation is organized in manuscript format. The two manuscripts were submitted to academic journals and, after going through the review process, were both accepted for publication in the first half of 2020.

The first manuscript, entitled:

The Dark Side of Narrow Gamification: Negative Impact of Assessment Gamification on Student Perceptions and Content Knowledge was accepted in April 2020 for publication in INFORMS Transactions on Education.

The second manuscript, entitled:

\section{Op-ed Writing Project in Supply Chain Management Courses}

was accepted in May 2020 for publication in Decision Sciences Journal of Innovative

\section{Education.}

This dissertation is the first product of my pursuit in fun and excitement. While five years in graduate school is not nearly enough to explore the elusive entity of fun to one's content, I believe I have started my journey in understanding the many other faces of fun, and how to design life around it: I intend to pursue farther and deeper.

Hee Yoon Kwon

Charlestown, RI

July 2020 


\section{TABLE OF CONTENTS}

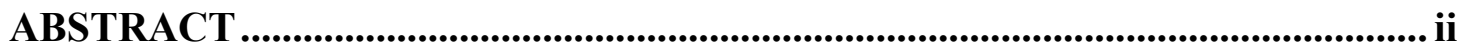

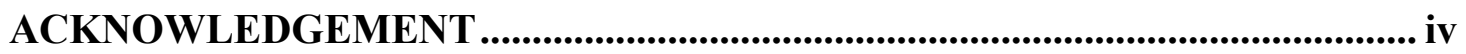

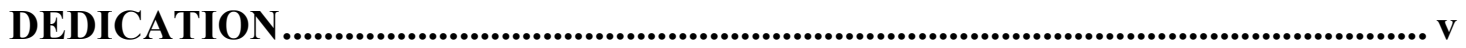

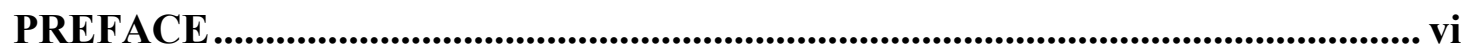

TABLE OF CONTENTS.................................................................................... vii

LIST OF TABLES ............................................................................................. ix

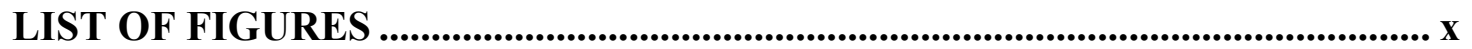

MANUSCRIPT ONE PUBLICATION STATUS ........................................... 1

MANUSCRIPT ONE | THE DARK SIDE OF NARROW GAMIFICATION:

NEGATIVE IMPACT OF ASSESSMENT GAMIFICATION ON STUDENT

PERCEPTIONS AND CONTENT KNOWLEDGE ................................................ 2

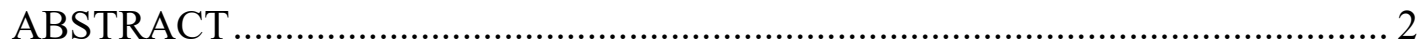

INTRODUCTION ................................................................................. 4

LITERATURE REVIEW .............................................................................. 5

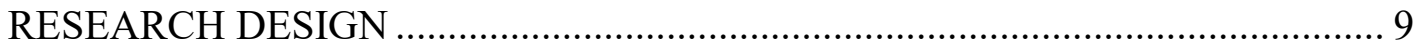

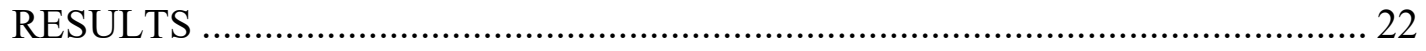

DISCUSSION AND SELF-REFLECTION .................................................... 30

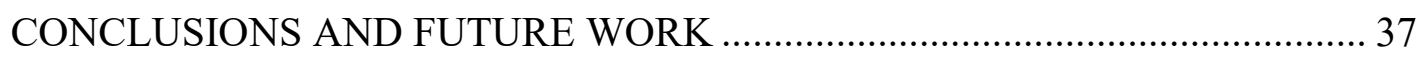

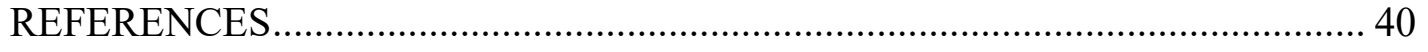




\section{MANUSCRIPT TWO | OP-ED WRITING PROJECT IN SUPPLY CHAIN}

MANAGEMENT COURSES........................................................................ 46

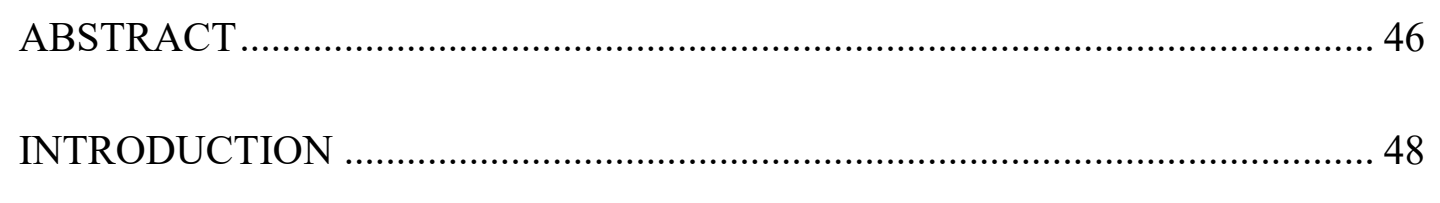

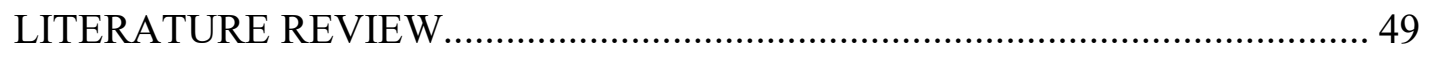

PROJECT OVERVIEW ........................................................................... 51

ASSESSMENT OF THE PROJECT …......................................................... 56

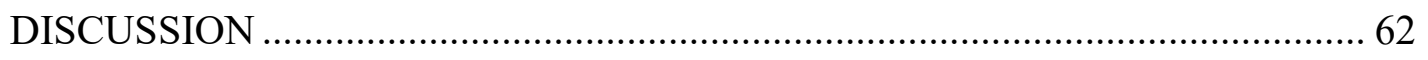

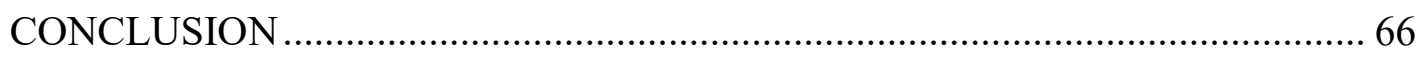

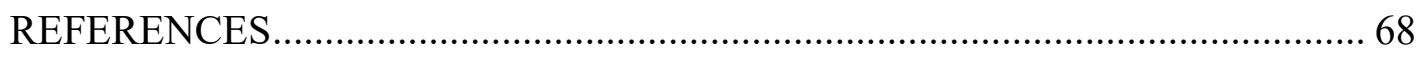

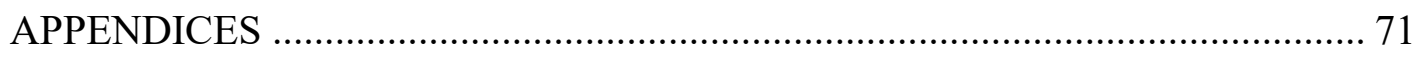




\section{LIST OF TABLES}

Table 1. Gamification Elements Applied to Course..................................................... 13

Table 2. Formative Survey Descriptive Statistics, by Group ……………………...... 19

Table 3. Summative Survey Descriptive Statistics ..................................................... 21

Table 4. Results of $t$-tests and descriptive statistics of Content Knowledge

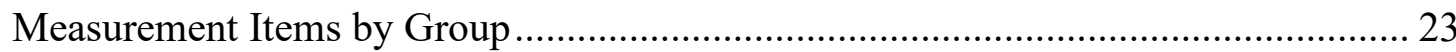

Table 5. Results of $t$-test and Descriptive Statistics of Dependent Variables by Group

Table 6. Fixed Effect ANOVA for Satisfaction ....................................................... 25

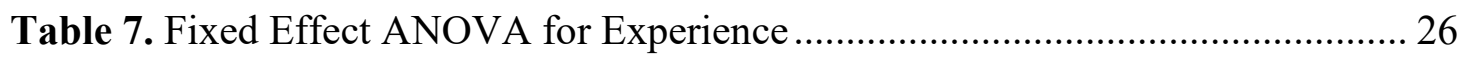

Table 8. Fixed Effect ANOVA for Perceived Learning ............................................... 27

Table 9. t-test Results and Descriptive Statistics of Impact of Teaching Technique

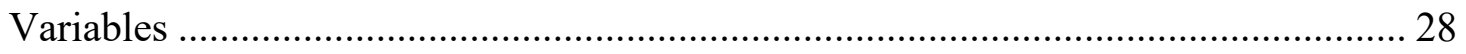

Table 10: Topics research project and op-ed writing ............................................ 52

Table 11: Demographic breakdown of students........................................................ 53

Table 12. Op-ed writing assignment milestones ………............................................. 54

Table 13. Summary of student responses to the greatest takeaway ........................... 59

Table 14. Summary of student responses to greatest challenge ……......................... 60

Table 15. Distribution of student responses to the project assessment survey $(n=67)$ 


\section{LIST OF FIGURES}

Figure 1. Flow of assessment activities............................................................. 11

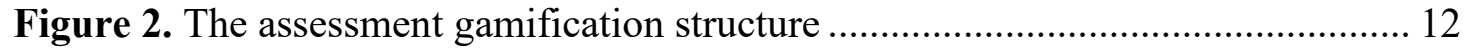

Figure 3. Quiz Scores by group and Date ........................................................ 23

Figure 4. The frequency of positive and negative words with "bing" \& "nrc" lexicon

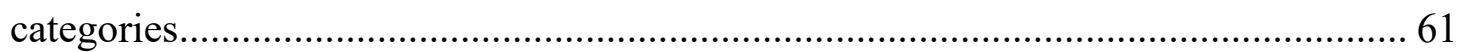


MANUSCRIPT ONE PUBLICATION STATUS

THE DARK SIDE OF NARROW GAMIFICATION:

NEGATIVE IMPACT OF ASSESSMENT GAMIFICATION

ON STUDENT PERCEPTIONS AND CONTENT KNOWLEDGE

\author{
Hee Yoon Kwon and Koray Özpolat \\ College of Business, University of Rhode Island, Kingston, RI, USA
}

This manuscript was accepted in April 2020 for publication in INFORMS Transactions on Education. 


\title{
MANUSCRIPT ONE
}

\section{THE DARK SIDE OF NARROW GAMIFICATION: NEGATIVE IMPACT OF ASSESSMENT GAMIFICATION ON STUDENT PERCEPTIONS AND CONTENT KNOWLEDGE}

\begin{abstract}
As gamification becomes more popular due to its benefits on engagement and motivation, application in higher education has been focused on developing electronic learning management systems, similar to those used in the industry for employee management. However, heavy reliance on technology for superficial gamification is hindering wider adoption and exploration of gamified course design by individual instructors. Also, the effects of gamification when applied selectively to specific areas of a course has not been extensively studied.

We gamified an operations and supply chain management course by implementing game mechanics and elements selectively to assessment activities. We used surveys to measure the effects of gamification on student perceptions of satisfaction, course experience, learning, impact of teaching method. Student's content knowledge was measured by quizzes and exam scores.

Interestingly, we found that gamifying assessment activities resulted in significantly lower content knowledge, satisfaction, and course experience. Difference in perceived learning was not significant. Also, team exam scores were significantly lower in the gamified group, while individual exam scores were not significantly different.
\end{abstract}


This study provides empirical evidence that gamification in classroom may produce unintended consequences and implementing gamification restrictively to assessment is ineffective at best. A holistic approach for gamified design is needed for a gamified course to be successful in engaging students and to achieve higher academic performance

Keywords: pedagogical research, teaching supply chain management, assessment, gamification. 


\section{INTRODUCTION}

"Games are showing us exactly what we want out of life: more satisfying work, better hope of success, stronger social connectivity, and the chance to be a part of something bigger than ourselves." - Jane McGonigal, Reality is broken (2011, p. 114)

In recent years, gamification has become more popular and pervasive in various contexts as a means of embracing the benefits of positive human emotions invoked by games (Seaborn \& Fels, 2015; Dias, 2017; Subhash \& Cudney, 2018). Gamification is noticed by academics, educators, and practitioners from a variety of domains, following a trend within the business and marketing sectors (Seaborn \& Fels, 2015). Specifically, gamification has been utilized and found to enhance motivation and improve user experience in brand loyalty (Zichermann \& Cunningham, 2011), healthcare and health awareness (Hamari \& Koivisto, 2015; González et al., 2016), management and training (Saunders, 2017), and education and learning (Buckley \& Doyle, 2014; Stansbury \& Earnest, 2016). Gamification by itself has become an emerging segment in the industry, expected to grow to over US\$22.9 billion by 2022 (P\&S Market Research, March 2016).

With a goal to bring some of these benefits to our classrooms, we gamified the assessment activities of an undergraduate level operations \& supply chain management (OSCM) course. The course is mandatory to all students majoring in business, and contains various concepts, constructs, and analytical content that requires high retention of student engagement for success. Specifically, reading the textbook to understand basic concepts and theories before lectures is crucial for student success, as well as to the efficient progression of the course. To this end, we implemented game mechanics 
and elements selectively to assessment activities of two sections of the OSCM course and measured the effects of gamification on student perceptions of satisfaction, course experience, learning, impact of teaching method, and student's content knowledge. Contrary to our expectations, gamification of assessment activities hurt students' content knowledge, satisfaction and course experience. This study contributes to the literature by demonstrating a dark side of gamification in a classroom setting and by exploring the effects of selectively gamifying a course design element (assessment) with no online platform involved.

The rest of the paper is structured as follows. First, an overview of gamification and its application in higher education is provided, followed by the theoretical background for gamification. The basis for selecting assessment activities as the focal area for gamification is clarified, accompanied by the experimental design and details on gamified assessment in the course. The method section outlines the data collection protocol and survey items. The findings are reported in the results section, followed by detailed analysis in the discussion section. Finally, major findings and implications are outlined in the conclusion, followed by limitations and directions for future research.

\section{LITERATURE REVIEW}

\section{Gamification in Higher Education}

Gamification is emerging as a research topic in higher education among various disciplines (Seaborn \& Fels, 2015). We adopt the definition of gamification as the "process of enhancing a service with affordances for gameful experiences in order to support user's overall value creation (Huotari \& Hamari, 2012, p. 19)”. Gamification differs from game-based learning (GBL) in that gamification uses elements and 
mechanics of videogames to improve user experience and engagement in non-game contexts (Aldemir et al., 2018), whereas GBL utilizes full-fledged games or videogames, often labeled "serious games", incorporated to the curriculum activities, as described by Kong (2019).

Educators from various disciplines have demonstrated benefits of gamification in higher education with evidence of improved attitude, engagement, enjoyment, motivation, (perceived) learning, participation, practical skills, retention, satisfaction, and student performance (grades) (Aldemir et al., 2018; Subhash \& Cudney, 2018). Subhash \& Cudney, through a systematic review of the literature focusing on gamified learning in higher education, reveal a growing number of research in recent years, as well as put business-related research in the second most published subject area after computing (Subhash \& Cudney, 2018).

A large body of gamification research has focused heavily on technology to create gamified experiences (Stansbury \& Earnest, 2016). In the education literature, the majority of gamification research in higher education entail the use and/or development of a dedicated online platform or a gamified learning management system (G-LMS) (Villagrasa, Fonseca, Redondo, \& Duran, 2014; de-Marcos, García-Cabot, \& García-López, 2017; Dias, 2017). This focus and reliance on technology may be hindering the wider adoption of gamification in higher education, due to the difficulty of designing and managing a complex information system (Sobocinski, 2017). There is a paucity of research in how gamification can be implemented without using or developing a complex technological system. Also, research on gamification of specific course design elements is desired, but remains scarce (Nacke \& Deterding, 2017) since 
most are focused on gamifying the full-scale course design and information systems development, which can be an overwhelming task and burden for any single instructor exploring the benefits of gamification without organizational support (Sobocinski, 2017).

Two recent exceptions stand out from these trends of technology dependence and full-scale points, badges, and leaderboards (PBL) approach in gamification research. Song (2017) designed a smaller-scale implementation of gamification focusing on the element of asking questions, examining the engaging effects of gamification within the individual and social interactions of the classroom (Song, 2017). Morillas Barrio, Munoz-Organero, and Sanchez Soriano (2016) found positive effects of gamified student response system (SRS) on student motivation, attention, and learning performance (Morillas Barrio et al., 2016). Their work also presented a novel path of gamification in higher education by implementing gamification around another innovative technique to enhance its benefits.

\section{Theoretical Background}

The majority of gamification research in the educational environment identify student engagement and motivation as core behavioral benefits of employing gamification (Hew, Huang, Chu, \& Chiu, 2016; Kuo \& Chuang, 2016; Subhash \& Cudney, 2018; Van Roy \& Zaman, 2018). Popularly cited in this stream of research is selfdetermination theory (SDT), which argues that "an understanding of human motivation requires a consideration of innate psychological needs for competence, autonomy, and relatedness (Deci \& Ryan, 2000, p. 227)”. Ryan and Deci (2000) identify the needs for competence, relatedness, and autonomy as essential for facilitating optimal functioning 
of the natural propensities for growth and integration, as well as for constructive social development and personal well-being (Ryan \& Deci, 2000). Deci and Ryan (2000) present a self-determination continuum, projecting type of motivation, type of regulation, and perceived locus of causality affecting varying degrees of selfdetermination. Intrinsic motivation is projected as most desirable type of motivation, in the extreme of self-determined behavior. Deci and Ryan (2000) also present intrinsic motivation, autonomous regulation of extrinsic motivation, and intrinsic aspirations as antecedents of high-quality performance, healthy behavior, and positive experiences.

Gamification research grounded in SDT can be categorized into structural and content gamification, according to the type of motivation (Kapp, Blair, \& Mesch, 2014; Hudiburg, 2016). Structural gamification relies on external motivation by adding game elements (e.g. points, badges, leaderboards) without altering content, whereas content gamification utilizes intrinsic motivation by applying game elements, mechanics, and thinking to the content, making an activity more game-like (Kapp et al., 2014; Hudiburg, 2016).

In the educational gamification research, intrinsic motivation is widely cited from SDT as desired outcome (Hew, Huang, Chu, \& Chiu, 2016; Kuo \& Chuang, 2016; Subhash \& Cudney, 2018; Van Roy \& Zaman, 2018). Intrinsically motivated students are more engaged, retain information better, and are generally happier (Hanus \& Fox, 2015). Intrinsic motivation is desired because the desire to learn comes from within the student, whereas extrinsic motivation is less desired, where the motivation is due to some outside force (Deci \& Ryan, 2000; Hanus \& Fox, 2015). In an empirical study of graduate students, Hew et al. (2016) find that students in the gamified course chose more 
difficult assignments and produced higher-quality artifacts than those in the nongamified course. We design assessment activities of the coursework with game mechanics following the suggestion of SDT on competence, relatedness, and autonomy.

\section{RESEARCH DESIGN}

\section{Design Elements and the Course Choice}

Considering the advice of many scholars on the need for careful design and alignment (de-Marcos et al., 2016; Fitz-Walter et al., 2017; Sobocinski, 2017; Aldemir et al., 2018), the ideal scenario for a course gamification design would be where the instructor can survey the students in advance to identify their needs and goals, thus customizing the gamified course design accordingly. In reality, however, most university students enroll in courses via an online system, and the course membership tends to change until the semester begins, as well as until weeks into the semester with drops and switches. Thus, the instructor rarely has a chance to meet or communicate with all of the enrolled students effectively until the semester begins. The alternative, then, is to identify the needs and goals that are vastly common among university students.

In higher education, students are exposed to high levels of stress and anxiety revolving their performance in assessments, such as quizzes, reports, and exams (Kapitanoff, 2009; Dahlström, 2012; Cantwell et al., 2017; Johanns, Dinkens, \& Moore, 2017; Levine et al., 2017; Khansari \& Coyne, 2018). In this research, we apply gamification on the course element of assessment activities with a reward structure that connects them towards midterm and final exams to explore its effects on students' content knowledge and perceptions on satisfaction, experience, learning, and impact of teaching methods. The focus on student satisfaction, explored by Reinig et al. (2011), 
addresses the remark of Jassawalla, Sashittal, and Malshe (2009): "What is curiously missing in the rich body of research is the perspective of the student (p.43)."

Finally, we decided to gamify the introductory operations and supply chain management (OSCM) course which is one of the most challenging courses to teach business students. Similar to Kong's (2019) motivation to choose a modeling and simulation course for game-based teaching, our choice of gamifying OSCM reflects our observations of business students being challenged by the analytical content (e.g., statistical process control, safety stocks, forecasting) in this course and the increased need to better engage students.

\section{Experimental Design}

For this study, two OSCM courses were designed. Both Section 1 (10 a.m.) and Section 2 (1 p.m.) were taught 3 times a week (Mon., Wed., Fri.) for 50 minutes each. Section 1 was designated as the experimental (gamified) group, while Section 2 was designated as the control (non-gamified) group. The two sections had the same instructor, course structure, learning objectives, assignments, quizzes, term projects, and exams. Section 1's curriculum had (i) a gamified structure of assessment activities, and (ii) an overlay of videogame nomenclature integrated to the assessment activities, following the application by Lieberoth (2015) and Stansbury and Earnest (2016).

Both sections were administered following a flipped classroom model (Herreid \& Schiller, 2013; Asef-Vaziri, 2015), where brief lectures were delivered to students via pre-recorded videos, uploaded to YouTube. Students from both sections had access to the same videos at the same time. The length and content of videos were limited so that they function as a study guide rather than a full lecture. Students were required to 
complete class preparation by reading the textbook and watching the study guide video before the class meeting.

Figure 1. Flow of assessment activities

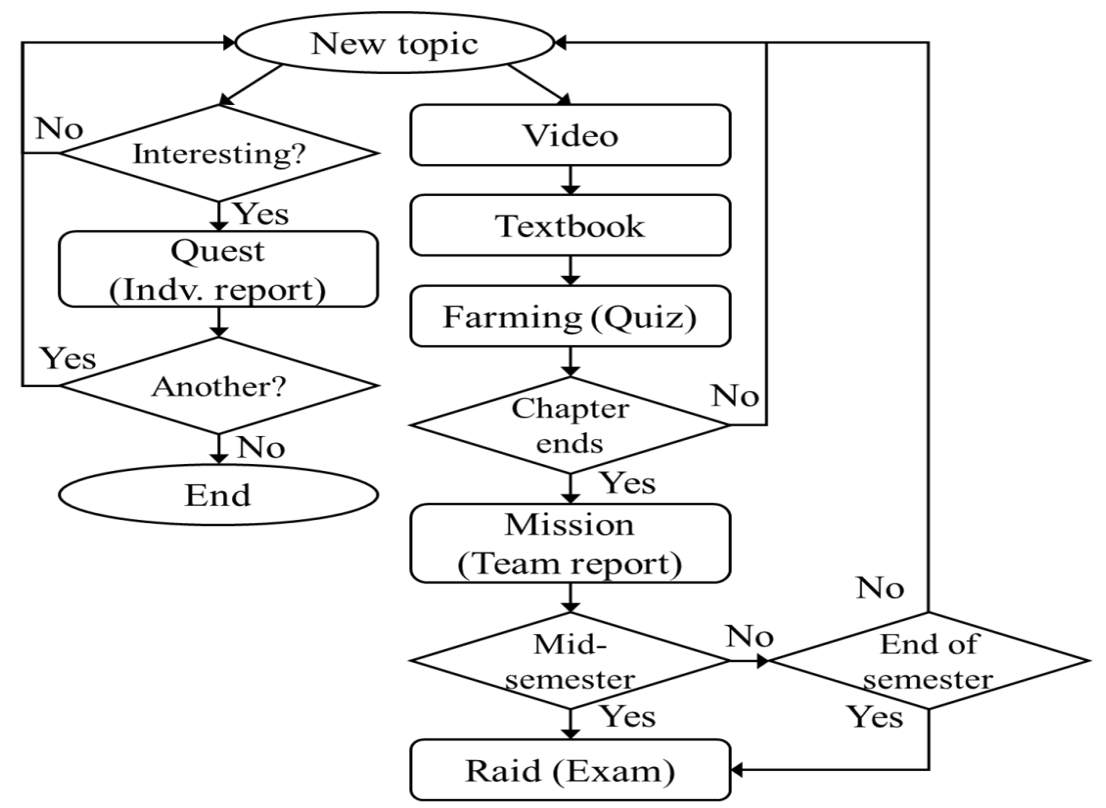

Figure 1 depicts the progression of assessment activities in a flowchart. In the first weeks of the semester, students were assigned to teams by the instructor to ensure membership diversity in terms of major, gender, age, and nationality; also, team membership was maintained throughout the semester (Koppenhaver \& Shrader, 2003). In both sections, a short quiz of 5 questions was administered at the beginning of each class session as formative assessment of content knowledge and attendance-taking. The quiz questions tested knowledge of key terminology and concepts. After finishing each chapter, student teams were required to produce chapter reports, in one of the following formats: writing, presentation slides, infographic, or video. Teams were required to identify key concepts and topics from the chapter and apply the knowledge to a realworld context. In both sections, one individual research report per semester was 
mandatory. Students were rewarded extra credit for each optional extra research report on some emerging supply chain topics.

The exams were designed as two-stage collaborative tests in both sections. Students were required to first individually answer questions of the individual exam, and then converge as a team to answer the questions of the team exam. The midterm exam consisted of 15 individual questions and 15 team questions. The final exam consisted of 20 individual questions and 20 team questions.

\section{Gamification in Course Assessment Activities}

Gamification was applied to this course by structuring assessment activities to build up towards the midterm and final exams with team rewards and by adding a layer of videogame-inspired nomenclature. Figure 2 depicts the gamified structure of assessment activities.

Figure 2. The assessment gamification structure

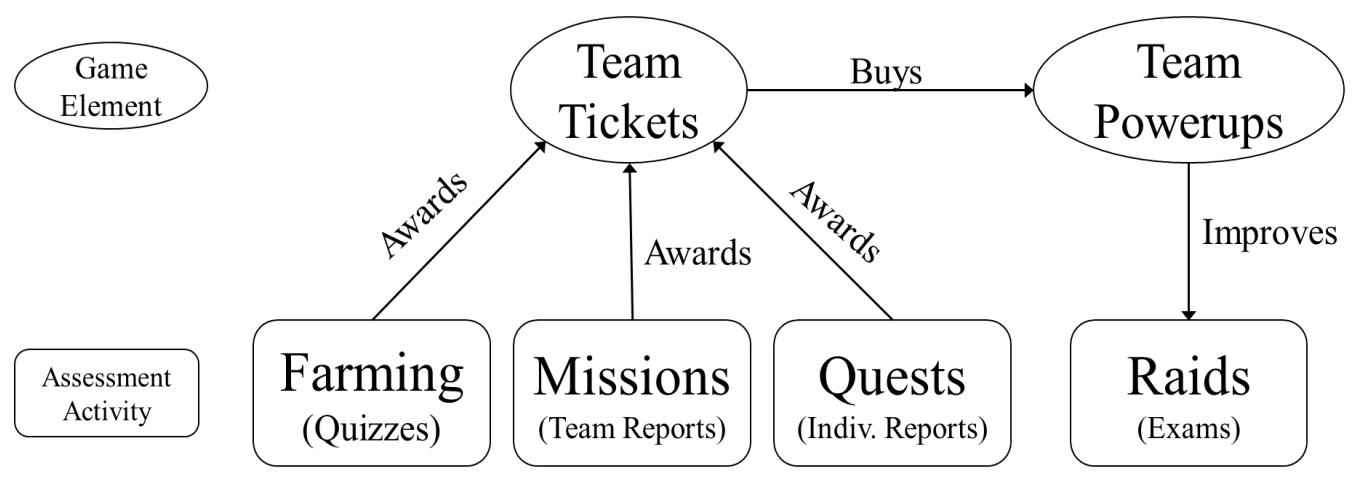

The quizzes were labelled 'Farming' and counted towards individual grades. Also, each team earned a ticket as a reward if all members of the team were present and scored higher than $60 \%$, and the team average score is higher than $80 \%$. Individual research report was labelled 'Quest'. Additional to individual grades and extra credit, a team ticket was rewarded for every additional individual report. The team chapter reports 
were labelled 'Missions'. On-time, high-quality output rewarded team tickets additional to team grade credits.

Table 1. Gamification Elements Applied to Course

\begin{tabular}{|c|c|c|c|}
\hline $\begin{array}{c}\text { Course Component / } \\
\text { Gamified Term } \\
\end{array}$ & $\begin{array}{c}\text { Non-gamified } \\
\text { Course Function } \\
\end{array}$ & Gamified Course Function & SDT Focus \\
\hline Quiz / Farming & $\begin{array}{l}\text { Proof of work, } \\
\text { attendance }\end{array}$ & & $\begin{array}{c}\text { Competence, } \\
\text { Relatedness }\end{array}$ \\
\hline $\begin{array}{c}\text { Team Chapter Report / } \\
\text { Mission }\end{array}$ & Team grade & $\begin{array}{c}\text { Team grade and } \\
\text { team tickets for Power-ups }\end{array}$ & $\begin{array}{l}\text { Competence, } \\
\text { Relatedness, } \\
\text { Autonomy }\end{array}$ \\
\hline $\begin{array}{c}\text { Individual Research Report } \\
\text { / Quest }\end{array}$ & $\begin{array}{l}\text { Individual } \\
\text { assignment, } \\
\text { extra credit }\end{array}$ & $\begin{array}{l}\text { Individual assignment, } \\
\text { extra credit, and team } \\
\text { tickets for Power-ups }\end{array}$ & $\begin{array}{l}\text { Autonomy, } \\
\text { Relatedness }\end{array}$ \\
\hline \multirow[b]{2}{*}{$\begin{array}{l}\text { Midterm and Final Exams / } \\
\text { Season } 1 \text { and } 2 \text { Boss Raids }\end{array}$} & $\begin{array}{l}\text { No structure in } \\
\text { question order }\end{array}$ & Progressive difficulty & Competence \\
\hline & $\begin{array}{c}1 \text { textbook, } \\
1 \text { calculator, } \\
1 \mathrm{pg} \text {. notes } \\
\text { available for teams }\end{array}$ & $\begin{array}{l}\text { 'Power-ups' earned with } \\
\text { team tickets from quizzes, } \\
\text { quests, raids }\end{array}$ & $\begin{array}{l}\text { Autonomy, } \\
\text { Relatedness }\end{array}$ \\
\hline
\end{tabular}

The midterm exam and the final exam were labelled 'Season 1 Boss Raid' and 'Season 2 Boss Raid', respectively. The individual exam was labelled "singleplayer", and the team exam was labelled "multiplayer". For the multiplayer, teams had conditional access to unique advantages, labelled "power-ups", such as one textbook, one calculator, and one page of hand-written notes. These power-ups were available for teams to purchase as a result of the team's performance and member contributions in Farming, Missions, and extra Quests, thereby connecting the basic activities of watching lecture videos and reading the textbook with the exams. Before each Raid (exam), teams were given ample opportunity to win more tickets than needed to purchase all three power-ups. In the control group, in contrast, one textbook, one calculator, and one page of hand-written notes were readily accessible to teams during the team exam. Table 1 
provides a comparison of how gamification was applied to assessment activities in the course, as well as the theoretical focus within SDT in each element.

Farming (quizzes) promotes competence through positive feedback. The quiz items ask basic conceptual questions, which is easy to answer if the student watched the video and read the textbook. The team reward system from Farming promotes relatedness. Missions (team chapter reports) promote all three focal areas of SDT: competence through adjustment of difficulty adequate to chapter progression (start with summaries and move on to case studies), relatedness through teamwork and team reward, and autonomy through meaningful choices for report format and case topic. Quest (individual research report) promotes autonomy through meaningful choice in topic selection, number of additional reports, and timing of submission, as well as relatedness through contribution to team reward for additional reports. Boss Raids (exams) promote competence through the progressive difficulty of questions, relatedness through collaborative exam, and autonomy through meaningful choice regarding which Power-up to purchase with the team reward tickets.

\section{Participants}

The study took place at a university in the northeast of the United States in the course of one semester in the fall of 2018. 62 undergraduate students participated, divided into two sections of 33 (Experimental, gamified) and 29 (Control, non-gamified) by enrollment. In order to control for selection bias, the online enrollment system displayed the same generic course description, standard to the College of Business, for the two sections. This way, students were not exposed to the pertinent experimental conditions and manipulations before enrolling. Information on the course design was only given 
after the semester started. OSCM is an introductory course that is required for all business major students of the university and is also open to students of other majors that satisfy the prerequisites. $19.35 \%$ of the students in the current study were female. $6.45 \%$ were freshmen, $29.03 \%$ were sophomores, while $53.23 \%$ were juniors, and $6.45 \%$ seniors. Specialized major areas of the students included supply chain management $(16.13 \%)$ to finance $(22.58 \%)$, marketing $(16.13 \%)$, accounting $(6.45 \%)$, management (8.06\%), chemical engineering, and communications.

\section{Measures and Procedures}

We tested the effect of assessment gamification on student's content knowledge, satisfaction with learning method, course experience, perception of learning, and impact of teaching techniques, following the survey methods of Stansbury and Earnest (2016) and Reinig et al. (2011), as detailed below. Content knowledge, course experience, perception of learning, and impact of teaching techniques were replicated or modified from Stansbury and Earnest (2016). Satisfaction with learning method was modified from Reinig et al. (2011).

\section{Content knowledge measures}

The content knowledge of students was calculated as the mean score of each student's total quiz and exam mean scores. At the beginning of every class session, a 5 -item quiz was given to students. Throughout the semester, a total of 24 quizzes were administered. The quiz items were either short-answer or multiple-choice questions on basic concepts of the session topic, which students were required to have studied in advance with the textbook and lecture video. Items on the quizzes were adapted from the test bank provided by the authors of the course textbook and were identical for both groups 
throughout the semester. Student performance on the quizzes was measured as a percentage of right answers. Because the quiz had a double purpose of attendance-taking, the quiz grade penalizes absenteeism, resulting in an inaccurate measurement of student's content knowledge. We resolved this issue by only accounting for quizzes taken at the time of class, excluding absentees from the average.

The midterm and final exam were administered as a 2-stage collaborative test with different sets of questions for each stage. Individual student performance in exams was measured as a percentage of right answers. The mean exam score was averaged with the mean quiz score to create a single variable, "Knowledge".

\section{Formative perception measures}

In the latter half of the semester, we conducted formative surveys in 8 different time points assessing student's perceived satisfaction with learning method, perceived experience, perceived learning, and perceived impact of teaching techniques used in the course. For the formative survey instrument, a 4-item perceived satisfaction survey from Reinig et al. (2011) was used. Also, a 4-item perceived experience survey and a 7-item perceived learning survey were adopted from Stansbury and Earnest (2016). A 7-item perceived impact of teaching method survey was adapted from Stansbury and Earnest (2016), with modifications to fit the context of course. Formative survey time points occurred over a 6 -week period between the $10^{\text {th }}$ and $15^{\text {th }}$ weeks of classes. The analysis used 176 accumulated surveys from the experimental group, and 167 accumulated surveys from the control group $(N=343)$. Table 2 provides a full list of survey items, constructs, and descriptive statistics. 
Items for perceived satisfaction with the learning method were adapted from the survey design of Reinig et al. (2011) and stated, "I feel satisfied with the learning method used in this class," "I liked the learning method used in this class," "I would like to use this learning method in other classes," and "I was happy with the learning method used in this class". Responses were measured on a 5-point Likert scale with end points: $1=$ strongly disagree to $5=$ strongly agree. All four items loaded onto a single construct. The items on this measure were highly reliable $(\alpha=.955)$. The mean score for the four satisfaction items was calculated as perceived satisfaction with learning method variable, "Satis".

Items for perceived course experience were modified from the survey design of Stansbury and Earnest (2016) and asked student's honest feelings on their course experience in six areas: motivating, engaging, fun, boring (inverse measure for fun), challenging, and relevant. Responses were measured on a 5-point Likert scale with end points: $1=$ strongly disagree to $5=$ strongly agree. The items on this measure were highly reliable $(\alpha=.813)$. The mean score for the six experience items was calculated as perceived course experience variable, "Exper".

Items for perceived learning were adapted from the survey design of Stansbury and Earnest (2016) and asked, "When comparing this course to my traditional courses, I would rate this course as being..." followed by 7 items including "motivating my learning" and "reinforcing key concepts". Responses were measured on a 5-point Likert scale with end points: $1=$ strongly disagree to $5=$ strongly agree. The items on the perceived learning measure were highly reliable $(\alpha=.934)$. The mean score for the seven perceived learning items was calculated as perceived learning variable, "Learn". 
Items for perceived impact of teaching technique measures were adapted from the survey design of Stansbury and Earnest (2016) and asked students how much their learning in the course was aided by seven teaching techniques: classroom discussions, team chapter reports, quizzes, professor, exams, lecture videos, and textbook. Responses were measured on a 7-point Likert scale with end points: $1=$ not at all to 5 $=$ extremely. The items on the perceived impact of teaching technique measure were treated as individual variables, following the suggestion of Stansbury and Earnest (2016). 
Table 2. Formative Survey Descriptive Statistics, by Group

\begin{tabular}{|c|c|c|c|c|}
\hline \multirow[b]{2}{*}{ Dependent Measures } & \multicolumn{2}{|c|}{$\begin{array}{c}\begin{array}{c}\text { Experimental } \\
\text { (gamified) Group }\end{array} \\
\quad N=176\end{array}$} & \multicolumn{2}{|c|}{$\begin{array}{c}\text { Control } \\
\text { (non-gamified) } \\
\text { Group } \\
N=167 \\
\end{array}$} \\
\hline & Mean & $S D$ & Mean & $S D$ \\
\hline $\begin{array}{l}\text { Perceived Satisfaction with the Learning } \\
\text { Method }^{* *}\end{array}$ & 4.04 & .79 & 4.22 & .68 \\
\hline $\begin{array}{l}\text { CS1 feel satisfied with the learning method } \\
\text { used in this class. }\end{array}$ & 4.04 & .062 & 4.29 & .057 \\
\hline $\begin{array}{l}\mathrm{CS} 2 \text { liked the learning method used in this } \\
\text { class. }\end{array}$ & 4.06 & .064 & 4.25 & .057 \\
\hline $\begin{array}{l}\text { CS3 I would like to use this learning method in } \\
\text { other classes. }\end{array}$ & 3.97 & .069 & 4.08 & .066 \\
\hline $\begin{array}{l}\text { CS4 I was happy with the learning method used } \\
\text { in this class. }\end{array}$ & 4.09 & .063 & 4.26 & .055 \\
\hline Perceived Course Experience ${ }^{b *}$ & 3.81 & .70 & 3.96 & .72 \\
\hline CE1 Motivating & 3.79 & .062 & 3.98 & .063 \\
\hline CE2 Engaging & 4.02 & .066 & 4.07 & .068 \\
\hline CE3 Fun & 3.93 & .061 & 3.86 & .07 \\
\hline CE4 Enjoyable ${ }^{c}$ & 3.49 & .073 & 3.93 & .072 \\
\hline Perceived Learning $^{\mathrm{d}}$ & 3.96 & .63 & 4.08 & .60 \\
\hline PL1 Increasing understanding of course content & 4.12 & .055 & 4.32 & .056 \\
\hline PL2 Increasing my confidence & 3.93 & .061 & 3.95 & .057 \\
\hline PL3 Keeping me involved in the classroom & 3.94 & .064 & 3.94 & .065 \\
\hline PL4 Reinforcing key concepts & 4.08 & .052 & 4.2 & .053 \\
\hline PL5 Motivating my la & 3.85 & .066 & 3.96 & .063 \\
\hline PL6 Developing my ability to reason & 3.76 & .064 & 3.91 & .065 \\
\hline PL7 Increasing application of course content & 4.04 & .059 & 4.26 & .058 \\
\hline \multicolumn{5}{|l|}{ Perceived Impact of Teaching Technique ${ }^{e}$} \\
\hline IT1 Group Activities & 5.39 & 1.12 & 5.51 & 1.15 \\
\hline IT2 Team Projects & 5.09 & 1.29 & 5.01 & 1.30 \\
\hline IT3 Quizzes & 5.43 & 1.12 & 5.37 & 1.26 \\
\hline IT4 Professor* & 5.52 & 1.26 & 5.81 & 1.28 \\
\hline IT5 Exams & 4.59 & 1.46 & 4.80 & 1.45 \\
\hline IT6 Lecture Videos*** & 4.18 & 1.63 & 4.72 & 1.42 \\
\hline IT7 Textbook*** & 5.59 & 1.30 & 4.90 & 1.77 \\
\hline
\end{tabular}

a, b, d. 5-Point Likert scales. $1=$ worse to $5=$ better.

e. 7-Point Likert scales. $1=$ not at all to $7=$ extremely.

c. Recoded from Inverse measure: "Boring".

${ }^{*} p<.05 .{ }^{* *} p<.01 .{ }^{* * *} p<.001$. 


\section{Summative perception measures}

We also conducted a 27-item summative follow-up survey for the experimental section at the end of the semester, after the final exam $(N=23)$. The summative perception survey contains 19 items on their overall perceived experience with the gamified course design (e.g. I enjoyed the gamified design of the class, the gamified design kept me engaged), 6 items on perceived efficacy of individual game elements (e.g. alteration of terms, reward system, and meaningful choices), as well as items on perception of videogames and learning (e.g. collaboration and teamwork, creativity and problemsolving) and learning style preference (competitive, cooperative, and individual). In the overall perceived experience measure and perceived efficacy of individual game elements measure, responses were assessed using a 5-point Likert scale with end points: $1=$ strongly disagree to $5=$ strongly agree. The perception of videogames and learning measure provided a list from which to select all that applies. The learning style preference measure provided a list from which to choose only one that applies. The items on the summative follow-up overall experience measure were highly reliable ( $\alpha$ $=.95$ ) and were explored to provide descriptive insights. Table 3 contains a full list of items and descriptive statistics. 
Table 3. Summative Survey Descriptive Statistics

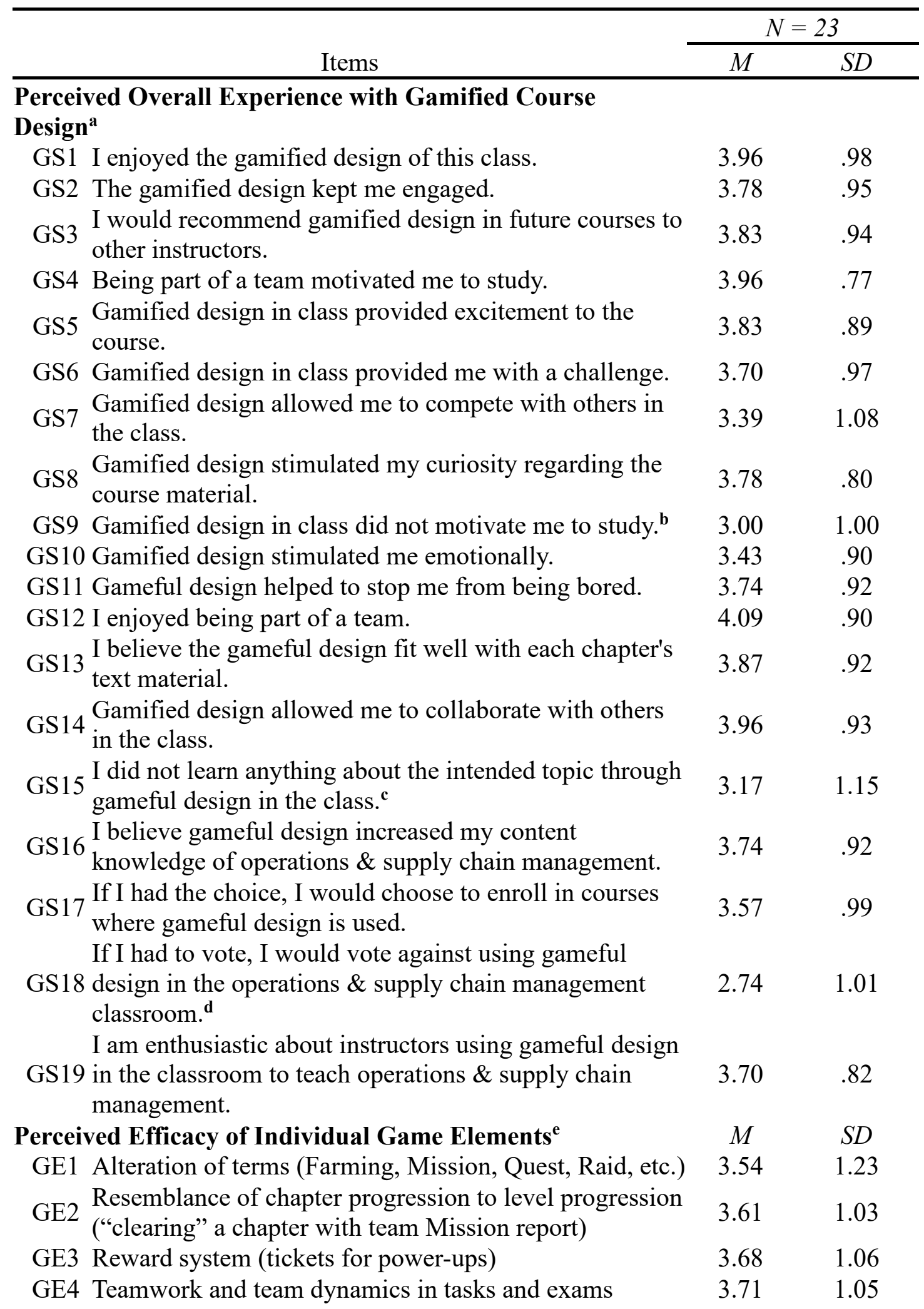


GE5 Meaningful choices (report format, number of reports, etc.)

b, c, d. Inversely measured.

a. 5-Point Likert scales. $1=$ strongly disagree to $5=$ strongly agree.

e. 5-Point Likert scales. $1=$ extremely negatively to $5=$ extremely positively.

\begin{tabular}{|c|c|c|}
\hline Perception of Skills Learned via Videogames & \multicolumn{2}{|c|}{ Percentage selected } \\
\hline SL1 Collaboration and teamwork & \multicolumn{2}{|c|}{$65 \%$} \\
\hline SL2 Creativity and problem-solving & \multicolumn{2}{|c|}{$65 \%$} \\
\hline SL3 Critical thinking and leading/motivating & \multicolumn{2}{|c|}{$52 \%$} \\
\hline SL4 Analyzing/classifying & \multicolumn{2}{|c|}{$52 \%$} \\
\hline Learning Style Preference ${ }^{f}$ & \multicolumn{2}{|c|}{ Selection Percentage } \\
\hline LS1 Working against other students & 4 & $17 \%$ \\
\hline LS2 Working with other students & 15 & $65 \%$ \\
\hline LS3 Working alone & 8 & $35 \%$ \\
\hline
\end{tabular}

f. Double selections counted.

\section{RESULTS}

\section{Content Knowledge}

\section{Quiz scores}

Results of a two-independent samples $t$-test (Table 4) shows that the mean score for quizzes taken differs between the experimental (gamified) group $(M=81.86, S D=$ 7.74, $n=33)$ and the control (non-gamified) group $(M=86.39, S D=7.67, n=29)$ at the .05 level of significance $(t=-2.31, d f=60, p=.024,95 \% C I[-0.085,-0.006])$. On average, students in the non-gamified control group scored higher in the quizzes than those in the gamified experimental group, as seen in Figure 3.

\section{Exam scores}

Scores from the midterm and final exams were divided into individual and team score from the two stages. A two-independent samples $t$-test shows that the total mean score for both exams differs between the experimental group $(M=70.71, S D=6.59, n=33)$ and the control group $(M=76.41, S D=7.46, n=29)$ at the .05 level of significance $(t$ 
Table 4. Results of $t$-tests and descriptive statistics of Content Knowledge Measurement Items by Group

\begin{tabular}{|c|c|c|c|c|c|c|c|c|c|}
\hline \multirow{2}{*}{$\begin{array}{l}\text { Measures } \\
\text { (percentage } \\
\text { score) }\end{array}$} & \multicolumn{2}{|c|}{$\begin{array}{c}\text { Experimental } \\
\text { Group } \\
N=33\end{array}$} & \multicolumn{2}{|c|}{$\begin{array}{l}\text { Control } \\
\text { Group } \\
N=29\end{array}$} & \multicolumn{2}{|c|}{$\begin{array}{c}95 \% C I \text { for } \\
\text { Mean } \\
\text { Difference }\end{array}$} & \multirow[b]{2}{*}{$t$} & \multirow[b]{2}{*}{$d f$} & \multirow{2}{*}{$\begin{array}{c}\text { Sig. } \\
\text { (2-tailed) }\end{array}$} \\
\hline & Mean & $S D$ & Mean & $S D$ & Lower & Upper & & & \\
\hline Quizzes Total & 81.86 & 7.74 & 86.39 & 7.67 & -0.085 & -0.006 & $-2.31 *$ & 60 & .024 \\
\hline Exams Total & 70.71 & 6.59 & 76.41 & 7.46 & -9.269 & -2.133 & $-3.20 * *$ & 60 & .002 \\
\hline \multicolumn{10}{|l|}{ Midterm Exam } \\
\hline Individual & 74.34 & 12.92 & 75.86 & 13.62 & -0.083 & 0.052 & -0.45 & 60 & .654 \\
\hline Team & 74.24 & 6.25 & 81.15 & 11.31 & -0.117 & -0.021 & $-2.92 * *$ & 42.37 & .006 \\
\hline Total & 74.29 & 6.07 & 78.51 & 7.94 & -0.078 & -0.006 & $-2.36^{*}$ & 60 & .021 \\
\hline \multicolumn{10}{|l|}{ Final Exam } \\
\hline Individual & 71.21 & 11.63 & 70.69 & 17.56 & -0.070 & 0.080 & 0.14 & 60 & .889 \\
\hline Team & 63.03 & 14.3 & 77.93 & 5.26 & -0.203 & -0.095 & $\begin{array}{c}- \\
5.57 * * *\end{array}$ & 41.5 & .000 \\
\hline Total & 67.12 & 9.77 & 74.31 & 9.28 & -0.120 & -0.023 & $-2.96 * *$ & 60 & .004 \\
\hline
\end{tabular}

Figure 3. Quiz Scores by group and Date

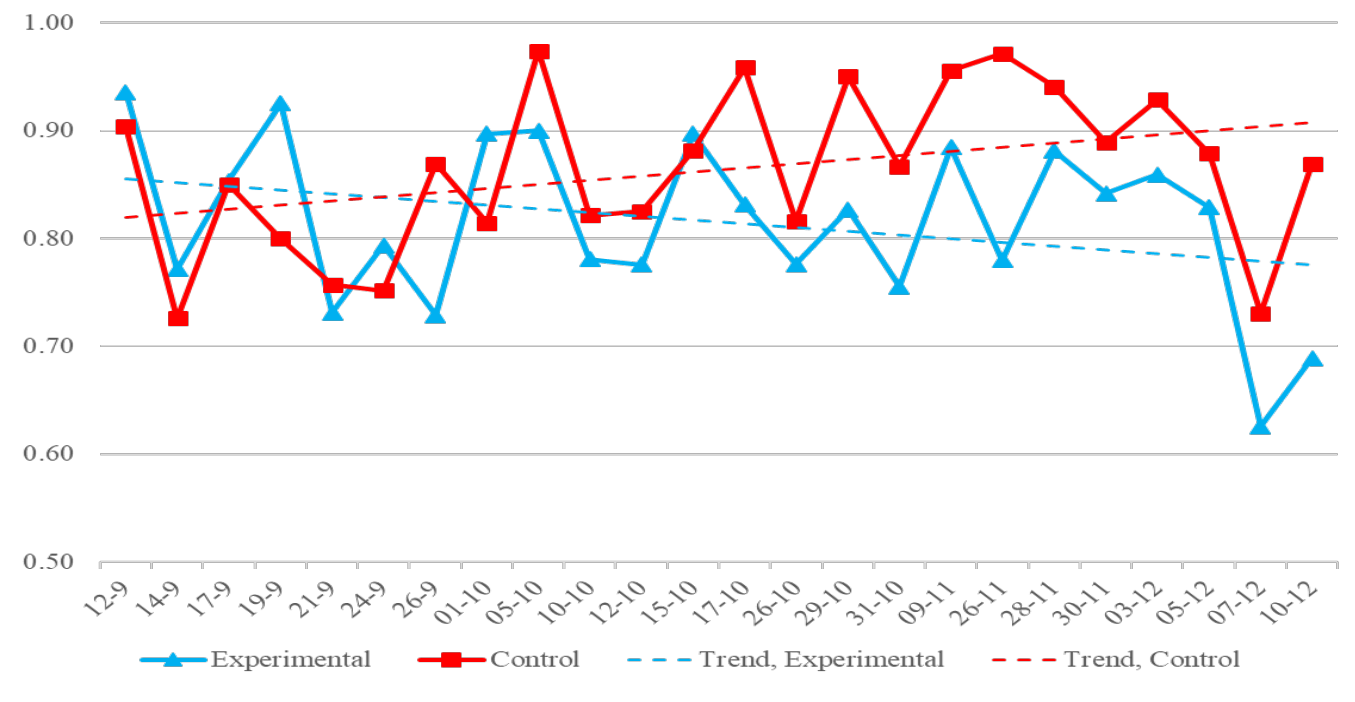

$=-3.20, d f=60, p=.002,95 \% C I[-9.269,-2.133])$. On average, students in the control group scored higher in the exams than those in the experimental group. Item-level analysis of the $t$-test on exam scores (Table 4) shows that students in the experimental 
group scored significantly less in the team exams in both midterm and final exams, their individual score mean is not significantly different in either exams. The experimental section's total mean scores of midterm $(M=74.29, S D=6.07, n=33)$ and final $(M=$ 67.12, $S D=9.77, n=33$ ) exams were both significantly lower than the control group's midterm $(M=78.51, S D=7.94, n=29)$ and final $(M=74.31, S D=9.28, n=29)$ total mean scores (Table 4).

The content knowledge variable calculated from quiz and exam mean scores shows significant difference between experimental group $(M=76.28, S D=6.47, n=$ 33) and control group $(M=81.40, S D=6.43, n=29)$ at .05 level of significance $(t=$ 3.12, $d f=60, p=.003,95 \% C I[-8.40,-1.83])$ (Table 5).

Table 5. Results of $t$-test and Descriptive Statistics of Dependent Variables by Group

\begin{tabular}{|c|c|c|c|c|c|c|c|c|c|}
\hline & & & oup & & & & & & \\
\hline & Expe & rimental & & ontrol & & $95 \%$ CI for & & & Sig. \\
\hline & $M$ & $S D \quad n$ & $M$ & $S D$ & $n$ & Mean Difference & $t$ & $d f$ & (2-tailed) \\
\hline Knowledge & 76.28 & 6.4733 & 81.40 & 6.43 & 29 & $-8.40,-1.83$ & $-3.12 * *$ & 60 & .003 \\
\hline Satisfaction & 4.04 & 0.79176 & 4.22 & 0.68 & 167 & $-.340,-.026$ & $-2.30 *$ & 341 & .022 \\
\hline Experience & 3.81 & 0.70176 & 3.96 & 0.72 & 167 & $-.302, .000$ & $-1.97 *$ & 341 & .050 \\
\hline Learning & 3.96 & 0.63176 & 4.08 & 0.60 & 167 & $-.246, .016$ & -1.73 & 341 & .085 \\
\hline
\end{tabular}

\section{Formative Perceptions}

\section{Perceived satisfaction with learning method}

Results of the two-independent samples $t$-test (Table 5) shows that the mean perceived satisfaction differs between the experimental $(M=4.04, S D=.79, n=176)$ and the control $(M=4.22, S D=.68, n=167)$ group at the .05 level of significance $(t=-2.30$, $d f=341, p=.022,95 \% C I$ for mean difference $[-.340,-.026])$. On average students in the experimental group were less satisfied with the learning method compared to those 
in the control section. The fixed effect ANOVA results (Table 6) show a significant between-group difference in satisfaction $(F=5.776, p=.017)$. There was no significant difference associated with survey sessions (SRV, proxy for time, $p=.806$ ) or the interaction of group (Sec) and survey session $(p=.504)$.

Table 6. Fixed Effect ANOVA for Satisfaction

Dependent Variable: Satis

\begin{tabular}{|c|c|c|c|c|c|c|c|c|}
\hline Source & Type III SS & $d f$ & $M S$ & $F$ & Sig. & $\begin{array}{c}\text { Partial } \\
\eta^{2} \\
\end{array}$ & $\begin{array}{l}\text { Noncent. } \\
\text { Parameter }\end{array}$ & $\begin{array}{c}\text { Observed } \\
\text { Power } \\
\end{array}$ \\
\hline $\begin{array}{l}\text { Corrected } \\
\text { Model }\end{array}$ & $8.396^{\mathrm{a}}$ & 15 & .560 & 1.017 & .437 & .045 & 15.256 & .665 \\
\hline Intercept & 5646.715 & 1 & 5646.715 & 10260.424 & 4.000 & .969 & 10260.424 & $\begin{array}{l}4 \quad 1.000 \\
\end{array}$ \\
\hline $\mathrm{Sec}$ & 3.178 & 1 & 3.178 & 5.776 & .017 & .017 & 5.776 & .669 \\
\hline SRV & 2.069 & 7 & 296 & .537 & .806 & .011 & 3.760 & .233 \\
\hline $\mathrm{Sec} * \mathrm{SRV}$ & 3.478 & 7 & .497 & .903 & .504 & .019 & 6.319 & .390 \\
\hline Error & 179.961 & 327 & .550 & & & & & \\
\hline Total & 6031.938 & 343 & & & & & & \\
\hline $\begin{array}{l}\text { Corrected } \\
\text { Total }\end{array}$ & 188.357 & 342 & & & & & & \\
\hline
\end{tabular}

a. R Squared $=.045$ (Adjusted $R$ Squared $=.001)$

b. Computed using alpha $=.05$

\section{Perceived course experience}

Results of the two-independent samples $t$-test (Table 5) shows that the mean perceived course experience differs between the experimental $(M=3.81, S D=.70, n=176)$ and the control $(M=3.96, S D=.72, n=167)$ group at the .05 level of significance $(t=$ $1.97, d f=341, p=.05,95 \% C I$ for mean difference $[-.302, .000])$. On average students in the experimental group had more negative experiences compared to those in the control section. The fixed effect ANOVA results (Table 7) show a significant betweengroup difference in experience $(F=4.323, p=.038)$. There was no significant difference 
associated with survey sessions (SRV, proxy for time, $p=.441)$ or the interaction of group (Sec) and survey session $(p=.947)$.

Table 7. Fixed Effect ANOVA for Experience

Dependent Variable: Exper

\begin{tabular}{|c|c|c|c|c|c|c|c|c|}
\hline Source & Type III SS & $d f$ & $M S$ & $F$ & Sig. & $\begin{array}{c}\text { Partial } \\
\eta^{2} \\
\end{array}$ & $\begin{array}{c}\text { Noncent. } \\
\text { Parameter }\end{array}$ & $\begin{array}{c}\text { Observed } \\
\text { Power }^{b}\end{array}$ \\
\hline $\begin{array}{l}\text { Corrected } \\
\text { Model }\end{array}$ & $6.626^{\mathrm{a}}$ & 15 & .442 & .862 & .608 & .038 & 12.927 & .572 \\
\hline Intercept & 4979.050 & 1 & 4979.050 & 9714.576 & .000 & .967 & 9714.576 & 1.000 \\
\hline $\mathrm{Sec}$ & 2.216 & 1 & 2.216 & 4.323 & .038 & .013 & 4.323 & .545 \\
\hline SRV & 3.539 & 7 & .506 & .986 & .441 & .021 & 6.905 & .426 \\
\hline $\mathrm{Sec} * \mathrm{SRV}$ & 1.132 & 7 & .162 & .316 & .947 & .007 & 2.210 & .146 \\
\hline Error & 167.599 & 327 & .513 & & & & & \\
\hline Total & 5339.125 & 343 & & & & & & \\
\hline $\begin{array}{l}\text { Corrected } \\
\text { Total }\end{array}$ & 174.224 & 342 & & & & & & \\
\hline
\end{tabular}

a. $\mathrm{R}$ Squared $=.038$ (Adjusted R Squared $=-.006$ )

b. Computed using alpha $=.05$

Perceived learning

Results of the two-independent samples $t$-test (Table 5) shows that the mean difference of perceived learning between the experimental $(M=3.96, S D=.63, n=176)$ and the control $(M=4.08, S D=.60, n=167)$ group is not significant at the .05 level of significance $(t=-1.73, d f=341, p=.085,95 \% C I$ for mean difference $[-.246, .016])$. The fixed effect ANOVA results (Table 8) show a non-significant between-group difference in perceived learning $(F=2.421, p=.121)$. 
Table 8. Fixed Effect ANOVA for Perceived Learning

Dependent Variable: Learn

\begin{tabular}{|c|c|c|c|c|c|c|c|c|}
\hline Source & Type III SS & $d f$ & $M S$ & $F$ & Sig. & $\begin{array}{c}\text { Partial } \\
\eta^{2}\end{array}$ & $\begin{array}{l}\text { Noncent. } \\
\text { Parameter }\end{array}$ & $\begin{array}{c}\text { Observed } \\
\text { Power }\end{array}$ \\
\hline $\begin{array}{l}\text { Corrected } \\
\text { Model }\end{array}$ & $4.732^{\mathrm{a}}$ & 15 & .315 & .816 & .659 & .036 & 12.244 & .543 \\
\hline Intercept & 5375.284 & 1 & 5375.284 & 13908.026 & .000 & .977 & 13908.026 & 1.000 \\
\hline $\mathrm{Sec}$ & .936 & 1 & .936 & 2.421 & .121 & .007 & 2.421 & .342 \\
\hline SRV & 1.722 & 7 & .246 & .636 & .726 & .013 & 4.455 & .274 \\
\hline $\mathrm{Sec} * \mathrm{SRV}$ & 1.875 & 7 & .268 & .693 & .678 & .015 & 4.850 & .299 \\
\hline Error & 126.382 & 327 & .386 & & & & & \\
\hline Total & 5663.776 & 343 & & & & & & \\
\hline $\begin{array}{l}\text { Corrected } \\
\text { Total }\end{array}$ & 131.114 & 342 & & & & & & \\
\hline
\end{tabular}

a. R Squared $=.036$ (Adjusted $R$ Squared $=-.008$ )

b. Computed using alpha $=.05$

\section{Perceived impact of teaching techniques}

Table 9 lists the t-test results for impact of teaching technique measurements. Students in the experimental group perceived the textbook $(M=5.59, S D=1.3, n=176)$ to aid their learning significantly more than students in the control group $(M=4.9, S D=.1 .8$, $n=167), t=4.04, d f=303.8, p=.000,95 \% C I$ for mean difference $[.349,1.013]$. Students in the control group perceived the professor $(M=5.8, S D=1.3, n=167)$ and lecture videos $(M=4.7, S D=1.4, n=167)$ to aid learning significantly more than in the experimental group (professor $M=5.52, S D=1.3, n=176$; lecture videos $M=4.18$, $S D=1.6, n=176)$. Group differences in other variables were not significant. In the experimental group, students reported highest impact of textbook, followed by professor, quizzes, and classroom discussions. Students in the control group report highest impact of professor, followed by classroom discussions and quizzes. 
A significantly higher mean score for impact of textbook supports the course design of utilizing gamification to motivate students to read the textbook before coming to class.

Table 9. t-test Results and Descriptive Statistics of Impact of Teaching Technique Variables

\begin{tabular}{|c|c|c|c|c|c|c|c|c|}
\hline \multirow[b]{3}{*}{ Variables } & \multicolumn{4}{|c|}{ Group } & \multirow{3}{*}{$\begin{array}{l}95 \% C I \text { for } \\
\text { Mean } \\
\text { Difference }\end{array}$} & \multirow[b]{3}{*}{$t$} & \multirow[b]{3}{*}{$d f$} & \multirow{3}{*}{$\begin{array}{c}\text { Sig. } \\
\text { (2-tailed) }\end{array}$} \\
\hline & \multicolumn{2}{|c|}{$\begin{array}{c}\text { Experimental } \\
N=176\end{array}$} & \multicolumn{2}{|c|}{$\begin{array}{l}\text { Control } \\
N=167 \\
\end{array}$} & & & & \\
\hline & $M$ & $S D$ & $M$ & $S D$ & & & & \\
\hline $\begin{array}{l}\text { Classroom } \\
\text { Discussions }\end{array}$ & 5.39 & 1.1 & 5.5 & 1.2 & $-.358, .124$ & -0.955 & 341 & 0.34 \\
\hline $\begin{array}{l}\text { Team Chapter } \\
\text { Reports }\end{array}$ & 5.09 & 1.3 & 5 & 1.3 & $-.196, .354$ & 0.565 & 341 & 0.573 \\
\hline Quizzes & 5.43 & 1.1 & 5.4 & 1.3 & $-.192, .313$ & 0.474 & 341 & 0.636 \\
\hline Professor & 5.52 & 1.3 & 5.8 & 1.3 & $-.555,-.016$ & $-2.08 *$ & 341 & 0.038 \\
\hline Exams & 4.59 & 1.5 & 4.8 & 1.5 & $-.521, .098$ & -1.34 & 341 & 0.18 \\
\hline $\begin{array}{l}\text { Lecture } \\
\text { Videos }\end{array}$ & 4.18 & 1.6 & 4.7 & 1.4 & $-.874,-.223$ & $-3.32 * * *$ & 341 & 0.001 \\
\hline Textbook & 5.59 & 1.3 & 4.9 & 1.8 & $.349,1.013$ & $4.04^{* * *}$ & $\begin{array}{c}303 \\
.8\end{array}$ & 0.000 \\
\hline
\end{tabular}

\section{Summative Perceptions}

The summative survey analysis with 19 items on gamification perceptions $(\alpha=.945)$ reveals that students in the experimental section had favorable perceptions towards most individual items (Table 3). It is notable that the highest mean score is reported on item GS12, "I enjoyed being a part of a team" $(M=4.09)$, followed by two other items regarding social dynamics: items GS4, "Being part of a team motivated me to study" $(M=3.96)$ and GS14, "Gamified design allowed me to collaborate with others in the class" $(M=3.96)$, because the design of gamified assessment in the course had a heavy focus on social interactions and teamwork. 
Students in the experimental group also reported overall positive perceptions towards individual game elements used in the course (Table 3). Again, students reported highest mean scores on item GE4, "teamwork and team dynamics in tasks and exams" ( $M=3.71$ ), followed by item GE3, "reward system (tickets for power-ups, $M=3.68$ ), which is also a social gamification element and the core driver for the gamified structure.

\section{Supplemental Analyses}

\section{Academic standing}

To check for a potential bias from student's previous academic standing on content knowledge, additional analyses were conducted to explore the possible effect of gamification on content knowledge, after taking student's cumulative grade point average (GPA) into account. A Scatter plot indicated a low degree of positive correlation between student's GPA and content knowledge. However, there was no significant difference between the two group's average cumulative GPA when the semester started. Thus, we can rule out the possibility that the difference in content knowledge and some perceptions between the experimental and control group were driven by previous academic standing.

\section{Gender}

Although the basic premise of gamification and SDT is that demographic differences do not matter, we ran another t-test for quiz scores, controlling for gender with the two groups combined. Female students $(N=13, M=84.07)$ show a significantly higher mean score compared to male students $(N=49, M=74.20)(t=2.543, d f=60, p=.014)$. In exam scores, female and male students show no significantly different scores. 
A bootstrap t-test on mean quiz scores of female students shows no significant difference between experimental $(N=6, M=83.84)$ and control $(N=7, M=89.56)$ group $(S E=4.221, p=.206,95 \% C I$ for mean difference $[-15.016,3.566])$. A bootstrap t-test on mean quiz scores of male students of experimental $(N=27, M=81.42)$ and control $(N=22, M=85.38)$ group resulted in no significant difference $(S E=2.117, p$ $=.070,95 \% C I$ for mean difference $[-7.994, .313])$. These analyses allow us to suggest that assessment gamification had no interaction with gender.

\section{DISCUSSION AND SELF-REFLECTION}

The results reported in Section 4 were surprising to us as we expected gamification of the OSCM course assessment element to have a positive impact on outcome variables. While there have been a few critiques of gamification in the literature, they mostly focused on the use PBL as a stock approach and its negative effects on students' intrinsic motivation (Deci, Costner \& Ryan, 1999; Aldemir, Celik \& Kaplan, 2018). Considering the advice of these critical studies, we avoided the classical PBL approach, gamified only one course element and used no online platform to design a generalizable course gamification experience. The surprising findings of our study make significant contributions to the literature by demonstrating a dark side of gamification in a classroom setting and by exploring the effects of selectively gamifying a course design element (assessment) with no online platform involved. Below, we will interpret our findings and reflect on our experiences to assist other professors design their own course gamification projects.

First, we would like to share a few positive observations of gamification that are more aligned with the literature. Students in the experimental group were vocal about 
their excitement and motivation towards the course. In more than one instance, a group of students in the experimental group would approach the instructor and express their excitement for the course, contrasting their frustration with another course that was not gamified. In an anonymous written survey, administered in the $9^{\text {th }}$ week, students responded with some positive comments such as "I really enjoy the videogame teaching style", "I like the videogame format", "the farming forces you to study almost daily", "I like that I have to rely on myself to teach myself", "I believe group work is very effective", and "I like how you offer the various ways we can do the mission reports because it helps me learn".

In addition, an analysis of perceived impact of teaching technique reveals that students in the gamified experimental group perceived the textbook as the most impactful resource, while those in the control group perceived the professor to be the most impactful element in their learning (Table 9). Student response to the instructor's proprietary midterm and final survey question on student perception of the textbook was overwhelmingly positive in the gamified group, whereas several in the control group expressed indifference or negative perceptions. This suggests that our iteration of assessment gamification motivated students to read the textbook before class to be ready and resulted in them being more self-regulating, which is associated with higher intrinsic motivation in SDT (Deci \& Ryan, 2000). Controlling for the effect of the flipped classroom design, which was identical across sections, gamification of assessment activities seems to have had positive effect on making students read the textbook. 
Our statistical results, interestingly, suggest that gamification of assessment significantly decreases student's content knowledge. The declining linear trend in the quiz scores from the experimental group is consistent with the observations made by Koivisto and Hamari (2014), where perceived usefulness, enjoyment, and playfulness are found to diminish with time interacting with gamified system. It is possible that gamifying assessment had some novelty value in the beginning of the semester resulting in higher motivation and engagement, but as students became accustomed to the course design and perceived the tasks as equally rudimentary as those in any other course, the novelty value may have faded and even harmed student performance in quizzes and exams. Lieberoth (2015) finds that adding a playful frame to tasks ("shallow gamification") takes away the grit and output orientation of more goal-oriented work, which may further explain the declining trend in the content knowledge of the experimental group.

Another reflection comes from the reward system. We used common rolled-up drink tickets as reward/currency in the gamified system. Although students appreciated being awarded tickets for their quiz and team assignment performances, the items themselves held little sentimental value. Regarding the effect of rewards on intrinsic motivation, the literature provides controversial viewpoints. Deci and Ryan (2000), based on findings of a meta-analytic review of studies on the effects of extrinsic rewards on intrinsic motivation, argue that tangible rewards that are expected and taskcontingent have negative impact on intrinsic motivation (Deci et al., 1999). In fact, Deci et al. (1999) find that all contingent tangible rewards, including monetary, significantly undermined intrinsic motivation, categorically refuting the argument of Eisenberger and 
Cameron (1996) that the detrimental effects of rewards is mostly a myth (Deci et al., 1999). However, these undermining effects of intrinsic motivation are only present in interesting tasks, not dull or boring ones (Deci et al., 1999). On the other hand, Aldemir et al. (2018), while extending the findings of Deci and Ryan (2000) with application on higher education, stress the need for a continuous and systematical reward distribution, with tangible items that are inexpensive but hold high sentimental value, to avoid students suddenly losing their motivation to continue. Enhanced aesthetic and sentimental value of the reward objects may enhance the prolonged engagement with the gamified system. The value of the reward was also found to be a major modulating factor in enhancing episodic memory (Mason, Farrell, Howard-Jones, \& Ludwig, 2017), making the association of high-value reward with an immersive experience an effective mechanism for gamification (Mullins \& Sabherwal, 2018).

A clearer disparity regarding the reward system exists between the unit of assessment and the unit of rewards. While the quizzes were given as individual assessments, the tickets were awarded for the team performance. Typically, teams assigned one member to collect and keep the awarded tickets (typically in a zip-lock plastic bag) while the rest of the team had no access to them. It appears that setting the team as the unit for rewards for individual assessments may have hindered the "slicing up" of motivating effects to the individual level. We suggest that rewards should, first and foremost, benefit the individual before the team in order to retain prolonged motivation and engagement of all team members. Considering the focus of SDT on the relationship between competence and intrinsic motivation (Deci \& Ryan, 2000), proper 
reward, adequately valuable to the perception of students, should be given to individuals in addition to the teams.

Another meaningful observation comes from the individual and team score differences between the two groups. A closer look at the content knowledge measurements reveals that the gamified group scored significantly lower than the control group in quizzes and team exams, but not in individual exam scores. These results suggest that gamification adversely affected student's team performance, while it did not affect their individual performance in the summative knowledge assessments. Hanus and Fox (2015) find that encouraging competition and social comparison harms intrinsic motivation, which in turn results in lower exam scores. Although their study environment uses an online leaderboard and badges, resulting in some degree of difference from the present study, the settings in present study may still invoke similar social comparison and competition. Specifically, after completing the quiz feedback, the instructor collected the quiz sheets by team and immediately awarded tickets to teams that qualified. Also, the instructor periodically asked teams to report the current quantity of tickets accumulated by each team.

The insights gained from the quizzes and exams show that the present gamification design involving the assessment of the course is, at best, insufficient to deliver a positive impact on student's content knowledge. This may be due to the long duration of the gamified experience, the simplistic reward system that rewards the team for individual work, and latent social competition that led to lower intrinsic motivation. It is apparent that the design needs to be improved to encompass more elements than assessment in order to retain student engagement and motivation, which will lead to 
enhanced content knowledge. Also, In the University's official course evaluation survey, one student from the experimental section commented: "Harder than most courses because students were expected to teach themselves. I wish the professor taught before we were quizzed". This suggests that the course's overall structure and the sequence of activities may interact with gamification.

\section{Student Perceptions}

The results of the formative perceptions survey suggest that assessment gamification had a significantly adverse effect on student's perception of satisfaction and course experience. However, perceived learning did not show a significant between-group difference. This suggests that, although our version of assessment gamification may have had a negative effect on student's satisfaction and course experience, they still felt like they were learning from the course. Also, it is important to note that, despite the significantly negative results in satisfaction and course experience in comparison with the control group, the survey results show that the gamified group is still highly satisfied $(M=4.04 / 5)$ and having an overall positive course experience $(M=3.81 / 5)($ Table $5)$.

These results and observations, combined together, suggest that students in the experimental section, as the initial hype and novelty value faded, perceived the gamified activities for coursework as what they actually are: coursework. Thus, they may have perceived slightly less satisfaction and poorer course experience overall due to certain degree of disillusionment as well as the negative effects of the reward system, but it did not result in a detrimental decline in satisfaction or experience. Also, they developed a sense of self-regulation and autonomy in reading the textbook before class. The 
cooperative social emphasis of gamification that builds every assessment activity up towards the exams also created a sense of accountability and team membership, apparent in the high mean scores in social aspect items of both formative perceptions survey (Table 2, IT1, IT2) and summative gamified course survey (Table 3, GS4, GS12, GS14, GE3, GE4), although they did not manifest as higher team exam scores. These results are consistent with the emphasis on the social aspect of gamification in the literature (Hamari \& Koivisto, 2015; de-Marcos et al., 2016; de-Marcos et al., 2017).

\section{Gamification of Assessment}

In the establishing work for SDT, Deci and Ryan (2000) refer to studies of Heider (1958) and de Charms (1968) on internal perceived locus of causality (PLOC), as well as additional studies that showed intrinsic motivation is undermined by threats, surveillance, evaluation, and deadlines because they shift the internal PLOC (I-PLOC) to external PLOC (E-PLOC). These studies are grounds on which Deci and Ryan (2000) argue the importance of satisfying the need for autonomy and sense of self-initiation for increased intrinsic motivation that can lead to greater creativity and better problemsolving.

In the present study, although choices were given for some components, such as team report format, the quizzes and exams were mandatory, and student performance in these mandatory activities had direct and heavy consequences in their grades. This is an issue especially prominent in the context of higher education, because it is nearly impossible to completely eliminate certain factors that may control or manipulate students in the current design for undergraduate-level coursework. In order to achieve 
the desired level of choices and autonomy, perhaps assessment shouldn't be the only element of the course to be gamified.

\section{CONCLUSIONS AND FUTURE WORK}

We are surprised to find that gamification of assessment activities of a course has negative impact on content knowledge and student perceptions. Our design was intended to explore the benefits that gamification can deliver to students when applied to course assessment. This design primarily answers the growing call for empirical studies on specific application contexts, as well as for isolating individual design elements. We did observe a heightened initial enthusiasm from the students for the gamified design, as well as the effect of gamification on promoting textbook reading before class. However, those observations did not lead to significant improvements in content knowledge and student perceptions, and even resulted in significantly inferior results. Our negative results suggest that gamification can hurt content knowledge and student perceptions when applied only to assessment of coursework. Instead of simplistic game mechanics applied to narrow areas of the coursework, the gamified system must encompass a multitude of mechanics and elements that can entertain various needs of students. This principle should apply across contexts: education, marketing, training, management, etc. This does not mean that gamification must be applied to all aspects of coursework to be successful. Finding the optimal mix of gamification in the coursework would be a valuable future study.

As gamification research matures, there has been a subtle but growing call for

elements of games and videogames that weren't emphasized in previous iterations of gamification in either business or academia. These are calls for elements that contribute 
to the ever-elusive aspect of fun; elements on which videogame developers and game makers spend enormous time and resources to develop, but somehow got lost in the transplantation of games to corporate and educational contexts: narrative and play style are among these elements. Narrative not only creates a more coherent experience, but also facilitates the need to be part of something bigger than oneself, as addressed by Mcgonigal (2011) in the opening quote of this study. an interdisciplinary team spanning from business, computer science, literature, theater, etc. may work best to design, implement, and execute a gamified coursework with rich, epic narratives and carefully placed elements and mechanics to deliver a fun, engaging, and effective learning experience.

This study extends the growing literature on gamification in higher education by implementing gamification to a narrower area of learning experience, focused on the

single course element: assessment, and used no online platform. Our analysis and observation lead to a conclusion that gamification is at best insignificant when applied only to assessment, and at worst may significantly harm student perceptions and academic performance.

\section{Limitations}

This study is limited in several ways. First, due to an iterative process of administrative approval for human subject research, the formative surveys were delayed until the $10^{\text {th }}$ week of the 16-week semester. As a result, while assessments in content knowledge span the entire semester, the data from the formative perceptions surveys are limited to the later third of the semester. Also, due to confidentiality and anonymity requirements, the surveys contained no identifiers of individual students. Therefore, we were unable 
to treat the survey as repeated measure to explore the effect of assessment gamification on individual student's perceptions over time. Although we do acknowledge this to be a major limitation, we opted for anonymity to avoid the possibility of students giving positively biased answers in the surveys due to coercion.

The quiz/exam scores and survey results of this study provide an interesting interpretation that lead to more questions. The controversial effect of rewards in a gamified system, as well as effect of different types and units of rewards, need more empirical testing as an isolated element. The effect of social interactions and the optimal mix of cooperation and competition, regarding their effects on intrinsic motivation, need to be addressed specifically in higher education context. 


\section{REFERENCES}

Aldemir, T., Celik, B., \& Kaplan, G. (2018). A qualitative investigation of student perceptions of game elements in a gamified course. Computers in Human Behavior, 78, 235-254. doi:10.1016/j.chb.2017.10.001

Asef-Vaziri, A. (2015). The flipped classroom of operations management: A not-forcost-reduction platform. Decision Sciences Journal of Innovative Education, 13(1). doi:10.1111/dsji.12054

Buckley, P., \& Doyle, E. (2014). Gamification and student motivation. Interactive Learning Environments, 24(6), 1162-1175. doi:10.1080/10494820.2014.964263

Dahlström, Ö. (2012). Learning during a collaborative final exam. Educational Research and Evaluation, 18(4), 321-332. doi:10.1080/13803611.2012.674689

de-Marcos, L., Garcia-Lopez, E., \& Garcia-Cabot, A. (2016). On the effectiveness of game-like and social approaches in learning: Comparing educational gaming, gamification \& social networking. Computers \& Education, 95, 99-113. doi:10.1016/j.compedu.2015.12.008

de-Marcos, L., García-Cabot, A., \& García-López, E. (2017). Towards the social gamification of e-learning: A practical experiment. International Journal of Engineering Educadion, 33, 66-73.

de Charms, R. (1968). Personal causation. New York: Academic.

Deci, E. L., Koestner, R., \& Ryan, R. M. (1999). A meta-analytic review of experiments examining the effects of extrinsic rewards on intrinsic motivation. Psychological Bulletin, 125(6), 627-668. doi:http://dx.doi.org/10.1037/00332909.125.6.627

Deci, E. L., \& Ryan, R. M. (2000). The "what" and "why" of goal pursuits: Human needs and the self-determination of behavior. Psychological Inquiry, 11(4), 227-268. doi:10.1207/S15327965PLI1104_01

Dias, J. (2017). Teaching operations research to undergraduate management students: The role of gamification. The International Journal of Management Education, 15(1), 98-111. doi:10.1016/j.ijme.2017.01.002

Eisenberger, R., \& Cameron, J. (1996). Detrimental effects of reward: Reality or myth? American Psychologist, 51(11), 1153-1166. doi:10.1037/0003066X.51.11.1153

Fitz-Walter, Z., Johnson, D., Wyeth, P., Tjondronegoro, D., \& Scott-Parker, B. (2017). Driven to drive? Investigating the effect of gamification on learner driver 
behavior, perceived motivation and user experience. Computers in Human Behavior, 71, 586-595. doi:10.1016/j.chb.2016.08.050

González, C. S., Gómez, N., Navarro, V., Cairós, M., Quirce, C., Toledo, P., \& Marrero-Gordillo, N. (2016). Learning healthy lifestyles through active videogames, motor games and the gamification of educational activities. Computers in Human Behavior, 55, 529-551. doi:10.1016/j.chb.2015.08.052

Hamari, J., \& Koivisto, J. (2015). "Working out for likes": An empirical study on social influence in exercise gamification. Computers in Human Behavior, 50, 333-347. doi:10.1016/j.chb.2015.04.018

Hanus, M. D., \& Fox, J. (2015). Assessing the effects of gamification in the classroom: A longitudinal study on intrinsic motivation, social comparison, satisfaction, effort, and academic performance. Computers \& Education, 80, 152-161. doi:10.1016/j.compedu.2014.08.019

Heider, F. (1958). The psychology of interpersonal relations. New York: Wiley.

Herreid, C. F., \& Schiller, N. A. (2013). Case studies and the flipped classroom. Journal of College Science Teaching, 42(5), 62-66.

Hew, K. F., Huang, B., Chu, K. W. S., \& Chiu, D. K. W. (2016). Engaging asian students through game mechanics: Findings from two experiment studies. Computers \& Education, 92-93, 221-236. doi:10.1016/j.compedu.2015.10.010

Hudiburg, M. L. (2016). Motivation and learning in an online collaborative project using gamification. (Ph.D Dissertation), Old Dominion University, Retrieved from https://digitalcommons.odu.edu/cgi/viewcontent.cgi?article=1004\&context=ste mps_etds

Huotari, K., \& Hamari, J. (2012) Defining gamification: A service marketing perspective. Proceeding of the 16th International Academic MindTrek Conference, Tampere, Finland. Association for Computing Machinery, New York, NY, United States. 17-22. https://doi.org/10.1145/2393132.2393137

Jassawalla, A., Sashittal, H., \& Malshe, A. (2009). Students' perceptions of social loafing: Its antecedents and consequences in undergraduate business classroom teams. Academy of Management Learning \& Education, 8(1), 42-54. doi: $10.2307 / 40214570$

Johanns, B., Dinkens, A., \& Moore, J. (2017). A systematic review comparing openbook and closed-book examinations: Evaluating effects on development of critical thinking skills. Nurse Education in Practice, 27, 89-94. doi:10.1016/j.nepr.2017.08.018 
Kapitanoff, S. H. (2009). Collaborative testing: Cognitive and interpersonal processes related to enhanced test performance. Active Learning in Higher Education, 10(1), 56-70. doi:10.1177/1469787408100195

Kapp, K. M., Blair, L., \& Mesch, R. (2014). The gamification of learning and instruction fieldbook San Francisco, CA: John Wiley \& Sons.

Khansari, P. S., \& Coyne, L. (2018). An innovative addition to team-based-learning pedagogy to enhance teaching and learning: Students' perceptions of team exams. Curr Pharm Teach Learn, 10(1), 90-95. doi:10.1016/j.cpt1.2017.09.009

Koivisto, J., \& Hamari, J. (2014). Demographic differences in perceived benefits from gamification. Computers in Human Behavior, 35, 179-188. doi:10.1016/j.chb.2014.03.007

Kong, N. (2019). Active game-based learning of dynamics modeling and simulation in biomedical systems engineering. INFORMS Transactions on Education, 20(1), 16-25. doi:10.1287/ited.2018.0205

Koppenhaver, G. D., \& Shrader, C. B. (2003). Structuring the classroom for performance: Cooperative learning with instructor-assigned teams. Decision Sciences Journal of Innovative Education, 1(1), 1-21. doi:10.1111/15405915.00002

Kuo, M.-S., \& Chuang, T.-Y. (2016). How gamification motivates visits and engagement for online academic dissemination - an empirical study. Computers in Human Behavior, 55, 16-27. doi:10.1016/j.chb.2015.08.025

Levine, R. E., Borges, N. J., Roman, B. J. B., Carchedi, L. R., Townsend, M. H., Cluver, J. S., . . . Thompson, B. M. (2017). High-stakes collaborative testing: Why not? Teaching and Learning in Medicine: An International Journal. doi:10.1080/10401334.2017.1365719

Lieberoth, A. (2015). Shallow gamification: Testing psychological effects of framing an activity as a game. Games and Culture, 10(3), 229-248. doi:10.1177/1555412014559978

Mason, A., Farrell, S., Howard-Jones, P., \& Ludwig, C. J. H. (2017). The role of reward and reward uncertainty in episodic memory. Journal of Memory and Language, 96, 62-77. doi:https://doi.org/10.1016/j.jml.2017.05.003

McGonigal, J. (2011). Reality is broken: Why games make us better and how they can change the world. New York: New York : Penguin Group.

Morillas Barrio, C., Munoz-Organero, M., \& Sanchez Soriano, J. (2016). Can gamification improve the benefits of student response systems in learning? An experimental study. IEEE Transactions on Emerging Topics in Computing, 4(3), 429-438. doi:10.1109/tetc.2015.2497459 
Mullins, J. K., \& Sabherwal, R. (2018). Gamification: A cognitive-emotional view. Journal of Business Research. doi:https://doi.org/10.1016/j.jbusres.2018.09.023

Nacke, L. E., \& Deterding, S. (2017). The maturing of gamification research. Computers in Human Behavior, 71, 450-454. doi:10.1016/j.chb.2016.11.062

Reinig, B. A., Horowitz, I., \& Whittenburg, G. E. (2011). The effect of team-based learning on student attitudes and satisfaction. Decision Sciences Journal of Innovative Education, 9(1), 27-47. doi:10.1111/j.1540-4609.2010.00289.x

P\&S Market Research (March 2016). Gamification market - market intelligence report, 2022. Retrieved from https://www.psmarketresearch.com/marketanalysis/gamification-market. Accessed October 10, 2019.

Ryan, R. M., \& Deci, E. L. (2000). Self-determination theory and the facilitation of intrinsic motivation, social development, and well-being. American Psychologist, 55(1), 68-78. doi:http://dx.doi.org.uri.idm.oclc.org/10.1037/0003-066X.55.1.68

Saunders, M. E. (2017). Gamification in employee training and development: Millennial perspectives. (Ph.D Dissertation), University of the Rockies, Denver, CO.

Seaborn, K., \& Fels, D. I. (2015). Gamification in theory and action: A survey. International Journal of Human-Computer Studies, 74, 14-31. doi:10.1016/j.ijhes.2014.09.006

Sobocinski, M. (2017). I gamified my courses and i hate that.... World Journal of Science, Technology and Sustainable Development, 14(2/3), 135-142. doi:10.1108/wjstsd-06-2016-0046

Song, D. (2017). Engaged cohorts: Can gamification engage all college students in class? EURASIA Journal of Mathematics, Science and Technology Education, 13. doi:10.12973/eurasia.2017.00755a

Stansbury, J. A., \& Earnest, D. R. (2016). Meaningful gamification in an industrial/organizational psychology course. Teaching of Psychology, 44(1), 38-45. doi:10.1177/0098628316677645

Subhash, S., \& Cudney, E. A. (2018). Gamified learning in higher education: A systematic review of the literature. Computers in Human Behavior, 87, 192206. doi:https://doi.org/10.1016/j.chb.2018.05.028

van Roy, R., \& Zaman, B. (2018). Unravelling the ambivalent motivational power of gamification: A basic psychological needs perspective. International Journal of Human-Computer Studies. doi:10.1016/j.ijhcs.2018.04.009 
Villagrasa, S., Fonseca, D., Redondo, E., \& Duran, J. (2014). Teaching case of gamification and visual technologies for education. Journal of Cases on Information Technology, 16(4), 38-57. doi:10.4018/jcit.2014100104

Zichermann, G., \& Cunningham, C. (2011). Gamification by design: Implementing game mechanics in web and mobile apps. Sebastopol, CA: O'Reilly Media. 


\title{
MANUSCRIPT TWO PUBLICATION STATUS
}

\section{OP-ED WRITING PROJECT \\ IN SUPPLY CHAIN MANAGEMENT COURSES}

\author{
Hee Yoon Kwon ${ }^{1}$, Jiayuan Zhang ${ }^{1}$, Koray Özpolat ${ }^{1}$, Yufeng Lin $^{2}$, and Adolf Ng $^{2}$ \\ ${ }^{1}$ College of Business, University of Rhode Island, Kingston, RI, USA \\ ${ }^{2}$ Asper School of Business, University of Manitoba, Winnipeg, Manitoba, Canada
}

An expanded version of this manuscript was accepted in May 2020 for publication in Decision Sciences Journal of Innovative Education. 


\title{
MANUSCRIPT TWO
}

\section{OP-ED WRITING PROJECT IN SUPPLY CHAIN MANAGEMENT COURSES}

\begin{abstract}
College students that major in business strive for opportunities to apply their learning to the real world to be better prepared for their professional lives after college. Newspaper op-eds, dedicated to commentary essays from outside of a newspaper, function as a platform for the public to exchange opinions. We designed an op-ed writing project with the following learning goals: 1) to educate students on how to write an op-ed, which is a novel and unfamiliar writing style for most students; and 2) to educate students on how to publish their opinions in a newspaper, which includes how to interact with journalists.
\end{abstract}

We present an op-ed writing project for students enrolled in two sections of a Global Supply Chain Management (SCM) course. The project was given as a team project, and entailed writing an op-ed on a current topic related to global SCM and submitting them for publication in local and regional newspapers. We conducted a survey that included qualitative and quantitative questions on the perceived greatest takeaways, greatest challenges, and feelings on the project.

Seven student teams successfully published their op-eds in local and regional newspapers. Students were excited to learn they, too, can participate in the exchange of opinions in the public domain via op-eds. Many expressed content in learning a new style of writing, deviating from the typical academic report writing. Students 
perceived that this project helped them learn the course materials better, and their sentiment towards the project was predominantly positive.

Considering multiple student op-eds successfully published in local and regional newspapers, along with the positive survey results aligned with the learning goals of the op-ed writing project, we consider that the goals of this project were successfully achieved.

Subject Areas: Projects, Pedagogy, Supply Chain Management. 


\section{INTRODUCTION}

The "deepest responsibility" of the newspaper, Oakes wrote, was "the same responsibility ... that the college has for its students - the responsibility of making them think." Thus, a fundamental purpose of the editorial page was "to question, to debunk." "Diversity of opinion is the lifeblood of democracy," Oakes contended in a 1954 speech.

"The minute we begin to insist that everyone think the same way we think, our democratic way of life is in danger." John B. Oakes (N.Y. Times editorials editor that created the op-ed page), Requoted from Socolow (2010)

The outside commentary page of a newspaper, commonly referred to as op-eds for being on the "opposite of editorial page", publish opinion essays on various topics, even if the opinion is not aligned with the newspaper's own. Op-eds in newspapers, thus, function as "a forum for the exchange and clash of ideas...covering a whole broad range of intellectual interests" (Socolow, 2010, p. 286). The op-ed page offers greater opportunity for expressing one's opinions and ideas to writers and thinkers who have no institutional connection with the media, even if their opinions are contrary to the editorial team's views (The New York Times, September 21, 1970, p.42).

We demonstrate a case of integrating op-ed writing to upper division supply chain management (SCM) courses at a northeast U.S. university. The op-ed writing project was given as part of a semester-long team research project. Student teams were required to conduct independent research on emerging SCM topics, deliver a 30- 
minute presentation in the classroom, and write an op-ed article on their assigned topic. The learning goals of the op-ed writing project are: 1) to educate students on how to write an op-ed, which is a novel and unfamiliar writing style for most students; and 2) to educate students on how to publish their opinions in a newspaper, which includes how to interact with journalists. Channeling students to express their opinions on contemporary business/SCM topics for the benefit of the community, this project also fosters students' critical thinking capabilities and sense of social responsibility. These contributions are aligned with the goal of nurturing active thinkers that participate in the process of democracy by speaking up in the public fora on issues that are important to their communities and professions, thus returning benefits of their university education to the public.

We also demonstrate an alternative implementation of the op-ed writing project with a different approach for the topics. Instead of an array of contemporary SCM topics, the alternative implementation uses a case study based on a local supply chain disruption.

\section{LITERATURE REVIEW}

The benefits of incorporating op-ed writing in coursework have been demonstrated by various scholars. J. C. Hall and Podemska-Mikluch (2015) showed that op-ed writing is the most conducive way of encouraging students to be sensible and active members of civil society, as well as active advocates of economic reasoning. Schneller (2016) demonstrated that op-ed writing can be used to help students develop and articulate their personal perspectives about environmental and sustainability issues. Calavita and Krumholz (2003) identified op-ed writing as highly visible public participation that 
can inform and invigorate teaching and help engage students. Poronnik and Moni (2006) found that although students perceived op-ed writing to be challenging, they also believed their ability to effectively communicate their knowledge to nonprofessional audiences in writing was improved after explicit teaching and feedback.

Our implementation of op-ed writing to coursework is based on active learning pedagogy. Active learning is defined as any instructional method that engages students in the learning process (Prince, 2004). It requires students to do meaningful learning activities and think about what they are doing (Prince, 2004; Bonwell and Eison, 1991). Bonwell and Eison (1991) summarized the literature on active learning and concluded that it leads to better student attitudes and improvements in student thinking and writing. Under this pedagogy, the Just-In-Time (JIT) exercise with Mega Blocks by Ashenbaum (2010) is one of many teaching innovations proposed in operations and supply chain management (Ellis, Goldsby, Bailey, and Oh, 2014; Hill and Baker, 2016; Brau, Gardner, Webb, \& Mcdonald, 2019).

Bringing the active learning pedagogy into the social responsibility domain, Özpolat, Chen, Hales, Yu, and Yalcin (2014) required students to design public service announcements in support of USAID's smart compassion campaign to address unsolicited material donations. Wentzel (1991), upon reviewing the literature on social responsibility and academic achievement, argues that "student social responsibility is not only a valued outcome in and of itself, but that it can be instrumental in the acquisition of knowledge and development of cognitive abilities (p.16)". Kingston, 
Maccartney, and Miller (2014) identify social responsibility as an integral element of preparing students for global citizenship.

The implementation of our op-ed writing project is also based on team-based learning (TBL) (Parmelee \& Michaelsen, 2010; Sweet \& Michaelsen, 2012; Khansari \& Coyne, 2018). TBL focuses on small group interaction more heavily than any other commonly used instructional strategy (Michaelsen and Sweet, 2008). With TBL, group work is central to exposing students to, and improving their ability to apply, course content (Michaelsen and Sweet, 2008). Students work in small groups to finish the op-ed writing project, and the interaction between students will improve their ability to apply the course content.

The remainder of this brief consists of a detailed layout of the project in the two classes at a northeast U.S. university. After the discussion of the case, we discuss the insights from various sources, along with specific suggestions for improved implementation.

\section{PROJECT OVERVIEW}

The implementation of the op-ed writing project took place in the spring semester of 2019 at a northeast U.S. university. Two sections of an upper division SCM course were taught by the same instructor on Tuesdays and Thursdays, at 09:30 AM (Section 1) and 11:00 AM (Section 2) for 75 minutes. The op-ed writing project was part of a semester-long team research project, which required student teams to (i) conduct independent research on an emergent SCM topic, (ii) make a 30-min. class presentation, and (iii-a) write an op-ed on the topic with the team's opinion and submit it to a local/regional media outlet or (iii-b) write a 10-page research report. The class 
presentation served as a demonstration of independent learning and research as well as team coordination. The op-ed/report writing complemented the research project as the written deliverable. The research project had 30 percent weight in the student's final grade -25 percent on self-initiated learning and class presentation, and 5 percent on the op-ed writing/research report project.

In the first week of the semester, the instructor assigned students into teams of four, ensuring that every team had at least two different business majors. From a menu of 12 topics provided by the instructor, student teams identified their top three choices and were assigned to one. The research topics were related to either cutting-edge supply chain technologies or contemporary global supply chain management. A full list of research topics is provided in Table 10.

Table 10: Topics research project and op-ed writing

\begin{aligned} & \hline 1 Uberization of last mile delivery \\ & 2 Blockchain and applications to SCM \\ & 3 Autonomous and electric trucks and implications on supply chains \\ & 4 Trans-Pacific Partnership Agreement (TPPA) and implications on global SCM \\ & 5 Rise of China and the One Belt One Road initiative \\ & 6 Industry 4.0: artificial intelligence and machine learning applications in SCM \\ & 7 Reshoring of U.S. manufacturing and foreign direct investment (FDI) in the U.S. \\ & 8 Additive Manufacturing (3D printing) and supply chain implications \\ & 9 The new Arctic Sea Route and global supply chain implications \\ & 10 Drone delivery in commercial and humanitarian supply chains \\ & 11 BREXIT: Britain's exit from the EU and implications on US supply chains \\ & 12 The new NAFTA and implications on North American supply chains \\ & \hline\end{aligned}

In both sections, students were required to conduct a thorough research in their assigned topic. The primary deliverable of the research was the classroom presentation, in which teams presented their research to their colleagues for 30 minutes. The op-ed writing project complemented the research project as a written deliverable. 
In Section 1, all teams were required to write an op-ed of 600-700 words as a written deliverable of the research project. In Section 2, teams had a choice between an op-ed of 600-700 words and a 10-page team research report. The research report was meant to be a written summary of their presentation, including their research process and findings. Because the instructor deemed this to be a relatively simple task, it was determined that the time and effort required for writing a 600-700-word op-ed, which was a novel writing style for most students, was comparable to that required for a 10-page research report. Interestingly, however, all teams of Section 2 opted for the op-ed writing project. All other conditions were kept identical between sections. At the end of the semester, questionnaires were distributed to students for data collection. The questionnaire included qualitative and quantitative items.

\section{Participants}

Section 1 had 44 students, while Section 2 had 49. All enrolled students were either juniors or seniors, and most were SCM or Marketing majors. Among the enrolled students, 56 were male and 37 were female. Table 11 shows the demographic breakdown of the students.

Table 11: Demographic breakdown of students

\begin{tabular}{rrcc}
\hline Variable & & $n$ & $\%$ \\
\hline Gender & Male & 56 & $60.2 \%$ \\
& Female & 37 & $39.8 \%$ \\
Year & Senior & 49 & $52.7 \%$ \\
& Junior & 44 & $47.3 \%$ \\
Major & SCM & 40 & $43.0 \%$ \\
& Marketing & 33 & $35.5 \%$ \\
& General business management & 11 & $11.8 \%$ \\
& Global business management & 6 & $6.5 \%$ \\
& Management & 2 & $2.2 \%$ \\
& Others & 1 & $1.0 \%$ \\
\hline
\end{tabular}




\section{Milestones}

In both sections, team presentations on research topics were spread out from the third week to the last week of classes. A first draft of the op-ed was due in the $9^{\text {th }}$ week. The TA provided feedback within a week, and the updated second draft was due in the $11^{\text {th }}$ week. Another round of review and feedback was provided in the same week, and a revised final draft was due in the $12^{\text {th }}$ week. After a brief last feedback in the same week, teams were required to submit the op-ed to a local/regional newspaper by the end of the $13^{\text {th }}$ week. If the first target newspaper rejected the manuscript, teams submitted to another newspaper by the end of the $14^{\text {th }}$ week. Table 12 provides a list of milestones.

Table 12. Op-ed writing project milestones

\begin{tabular}{ccc}
\hline Milestone & Submission Due & Deliverable \\
\hline 1 & 9th week & First draft \\
2 & 11th week & Second draft \\
3 & 12th week & Final draft \\
4 & 13th week & First submission \\
5 & 14th week & Second submission \\
\hline
\end{tabular}

\section{In-Class Introduction of Op-Ed Writing}

While the topic selection and classroom presentation portion of the team research project was guided and graded by the principal instructor who is an associate professor, the op-ed writing portion was guided and graded by a graduate teaching assistant (TA) at the doctoral level. The TA made a 20-minute in-class presentation in the fourth week of the semester, introducing the purpose, function, and format of oped writing. The detail of the op-ed writing project within the team research project was also covered. Three online articles (Omang, 2008; T. Hall, 2013; Duke University, 2019) on op-ed writing guidelines were shared with the students on the syllabi and 
during TA presentation. Also, the TA introduced a few op-ed articles written and published by previous semester's students to demonstrate not only the structure of an op-ed but also the feasibility of student publications.

\section{Grading}

Regarding what constitutes a good op-ed article, we referred to resources available online (Omang, 2008; T. Hall, 2013; Duke University, 2019) to identify several important components: a strong hook to grasp the reader's attention at the beginning, a strong argument with personal voice, demonstrated personal connections to the readers, plentiful evidence supporting the argument, specific recommendations or policy suggestions, and a concsise writing with $600-750$ words. Combining these components with the university's standards for academic writing projects (e.g. grammar, punctuation, structure, etc.), we created an op-ed grading rubric (Appendix A).

\section{Survey Administration}

An Institutional Review Board (IRB) approved survey was conducted in the last class session of the semester. The survey contained three open-ended qualitative questions, as well as eight quantitative questions adapted from related studies (Sun, Flores, \& Tanguma, 2012; Erzurumlu \& Rollag, 2013; Hill \& Baker, 2016; Li, Marsh, \& Rienties, 2016; Stansbury \& Earnest, 2017; Selfdeterminationtheory.Org, 2018). The analysis used 34 returned surveys from Section 1 and 33 returned surveys from Section $2(N=67)$. 


\section{ASSESSMENT OF THE PROJECT}

\section{The Experience: TA Review, Submissions, and Publications}

As specified in Table 12, student teams submitted their first draft op-ed in MS Word format at the end of the $9^{\text {th }}$ week. The TA received the submissions via e-mail from each team and provided written feedback in the form of edits and electronic memos on the MS Word document. The first draft feedback was predominantly on conformity to the op-ed format, since the majority of teams were following the familiar academic report format. A specifically prevalent issue was the lack of opinion in the writing, since summarizing their research project alone tended to take up most of the 600-to700-word limit. Another widespread issue was the lack of a strong hook in the first paragraph that grasps the attention of the reader. The first round of review and feedback for the 23 manuscripts took the TA a full week to review, and the student teams had a week to work on the revision and resubmit the second. The TA also posted general feedback in the Announcement board of the learning management system (LMS), along with instructions for the second draft submission. TA's first general feedback is provided in Appendix B.

The second draft submission saw significant improvement in several teams, yet many teams were still stuck at the academic format. Some made a transition into a news article, establishing relevance between the topic and local/regional/national implications but still lacking a strong opinion. Prevalent issues in the second round also included the first paragraph not containing the main point, ambiguous and broad suggestions and solutions, and too much detailed information. The second round of review and feedback for the 23 manuscripts took the TA four days to review, and the 
student teams had four days to work on the revision and resubmit the final draft to the TA. The TA also posted a general feedback in the Announcement board of the LMS, along with instructions for the final draft submission. Preparing students for the final stage, the instructor and TA provided a list of local media outlets for the students to consider. The second general feedback is provided in Appendix C. At this time, the TA also provided a sample cover letter for submission to the editor. The sample cover letter is provided in Appendix D.

The final draft submission saw significant advances in many team's manuscripts, and the reviews were finished in one day. The TA gave teams specific instructions for formatting their manuscripts and submitting them to one local/regional newspaper within 24 hours. Students were instructed not to reveal the fact that their manuscript is part of a course project but take full ownership of the submission. The initial submission instructions are provided in Appendix E. A week after the initial submission, the TA posted instructions for withdrawal and resubmission to another newspaper for those teams with no acceptance. Students were instructed to send a letter of withdrawal to the editor if the editor didn't respond to their initial submission within 12 days. The TA graded each team's op-ed manuscript based on the op-ed grading rubric developed from multiple resources on op-ed writing (Omang, 2008; T. Hall, 2013; Duke University, 2019) and the university's academic writing rubric. The average score of Section 1 was 90.1 out of 100 , and that of Section 2 was 92.8. The average of both sections at 91.4 signifies that the first learning goal of educating students how to write an op-ed was achieved. 
14 out of 23 manuscripts were initially submitted to a prime regional newspaper. Three teams initially submitted to a regional business newspaper. Three other teams submitted to local newspapers, and one submitted to the university newspaper. Out of the initial submissions, three teams were accepted and published in the business newspaper and two local newspapers. The second submission (after withdrawal from the first newspaper) was dispersed to various local newspapers. Three more teams published in two local newspapers. We provide hyperlinks to the published student op-eds in Appendix F. Seven student op-ed publications in local and regional newspapers and a practitioner journal signifies the second learning goal of educating students how to publish their opinions in a newspaper was achieved.

\section{Qualitative Survey}

Three qualitative questions were asked to explore student perceptions on the greatest takeaway and the greatest challenge from the op-ed writing project, as well as their feelings for the op-ed writing project. Two techniques and procedures were adopted from Kock, Verville, and Garza (2007) to code the qualitative responses. The first technique identified patterns across the textual data. Responses were categorized into several patterns, and the frequencies of the patterns were calculated as percentages (Miles \& Huberman, 1994; Yin, 2017). The second technique employed was content analysis. We applied manifest (semantic) content analysis and latent (inferred) content analysis (Wilson, 1989) on the patterns identified by the first method. The next sections discuss the results of the qualitative data analysis of the textual responses for the questions on the greatest takeaway, greatest challenge, and feelings towards the op-ed writing project. 


\section{Takeaway}

After iterative rounds of discussions among the authors, responses to the question on the greatest takeaway were coded into six categories (Voice, Learning, Community, Publication, Style, and Others). The Voice category includes illustrative quotations on how the op-ed writing project helps students to express their opinions on a news outlet. The Learning category includes illustrative quotations on how the project helps them learn the topics deeper. The Community category includes illustrative quotations on how the project helps them connect and contribute to their community. The Publication category includes illustrative quotations on how the project helps them learn how to publish on a newspaper. The Style category includes illustrative quotations on learning how to write an opinion column, which for many of our students was a novel style of writing. All those quotations that don't fall into the five categories specified above were coded into the Others category. Table 13 summarizes the illustrative quotations of each category.

Table 13. Summary of student responses to the greatest takeaway

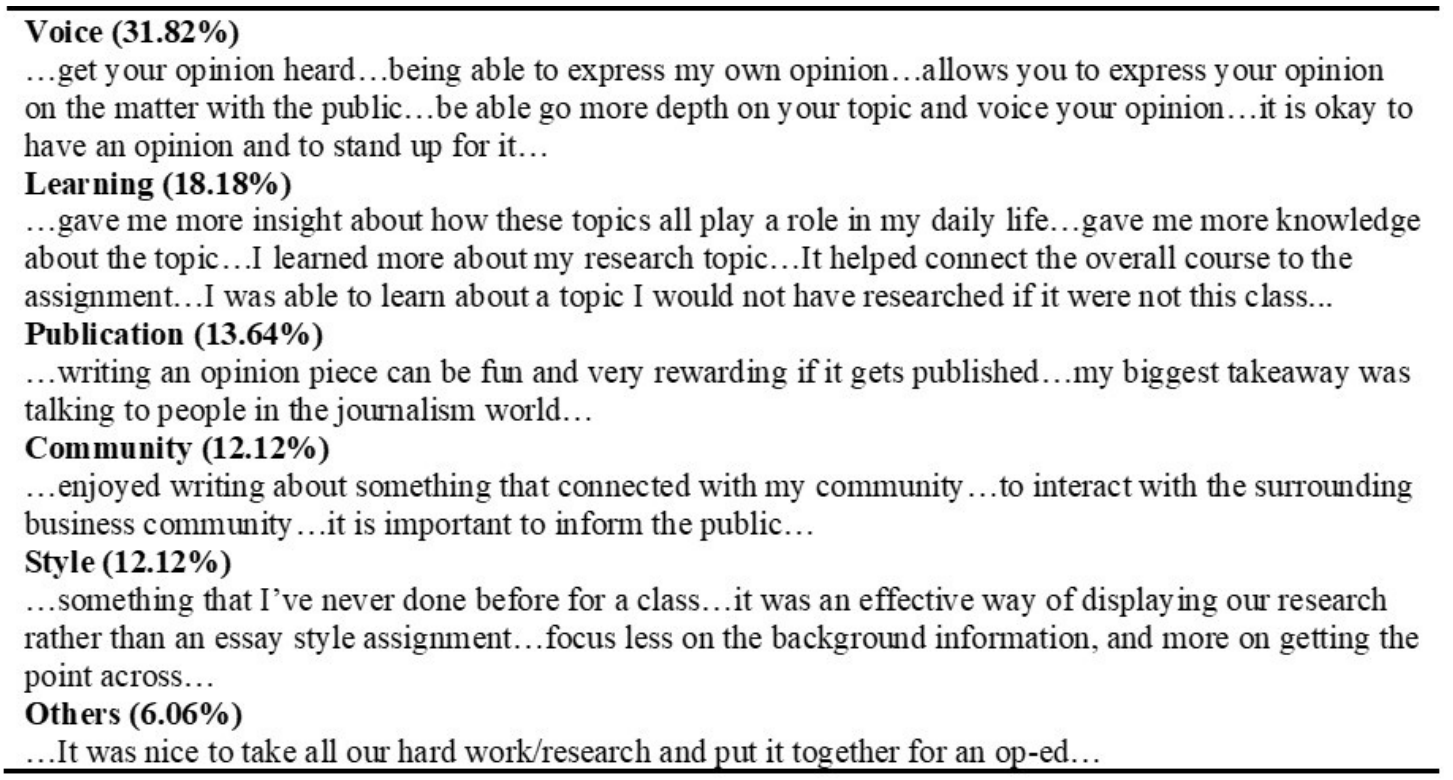




\section{Challenge}

Responses to the question on the greatest challenge were coded into seven categories (Teamwork, Opinion forming, Style, Publication, Relevance, Iterative review process, and Others). The Teamwork category includes illustrative quotations on the challenge of working as a team to write an op-ed article. The Opinion forming category includes illustrative quotations on the challenges of building a firm opinion. The Style category includes illustrative quotations on the challenges of learning a new writing style. The Publication category includes illustrative quotations on the challenges of being accepted for publication on a newspaper. The Relevance category includes illustrative quotations on the challenges of making meaningful connections between the generic topic and the regional context. The Iterative review process category includes illustrative quotations on the challenges of going through the TA-guided revision

Table 14. Summary of student responses to greatest challenge

Teamwork (43.94\%)

... all having own opinion on the topic and having to write one piece...merging opinions within the group...trying to have 4 people write an op-ed...having each group member write something different and make it flow nicely and all agree on the stated opinion...

Opinion forming (13.64\%)

...writing it the right way to make it more of an opinion than just all the facts...incorporating opinion vs. facts...trying to make my topic about an opinion rather than explaining what it is...choosing a position to agree for or against...having an opinion...

\section{Style (12.12\%)}

...following the format and balancing info and opinion...focusing on a specific rather than a broad scale...finding the correct way to write it...getting everything we needed to say into only 700 words...

Publication (12.12\%)

...getting published...getting accepted by publisher...finding a newspaper to publish it... it is much harder to get op-ed published than I thought...

\section{Relevance $\mathbf{( 7 . 5 8 \% )}$}

...our biggest challenge was including the most relevant information and condensing it...finding an example of an RI business that would benefit from investing in industry 4.0 ...finding a topic that is relevant to us and coming up with an interesting portion of it to write about...

Iterative review process $(6.06 \%)$

...there were a lot of revisions that need to be done...the feedback and making those changes...

Others $(4.55 \%)$

...it was hard to do after so many weeks of doing research project... 
process. All the quotations that don't fall into the six challenge categories specified above were coded into the Others category. Table 14 summarizes the illustrative quotations for each category.

\section{Feelings}

The responses to the question asking how students feel about the op-ed writing project were first categorized for overall feeling, in Positive (57.81\%), Neutral (26.56\%), and Negative (15.63\%). To validate the categorization, the authors ran a sentiment analysis with R-studio. The responses were compared to the "bing" and "nrc" lexicon, which identify specific, pre-determined words in responses as criteria for categorization. The "bing" lexicon categorizes each response into a Positive-Negative dichotomy (Figure 4), identifying 37 positive responses and 5 negative responses. The "nrc" lexicon categorizes each response to one of ten categories (Figure 4), identifying 79 positive responses (Positive, Trust, Joy, Anticipation, and surprise) and 20 negative responses (Negative, Fear, Sadness, Anger, and Disgust). These results indicate that students feel overwhelmingly positive toward the op-ed writing project.

Figure 4. The frequency of positive and negative words with "bing" \& "nrc" lexicon categories

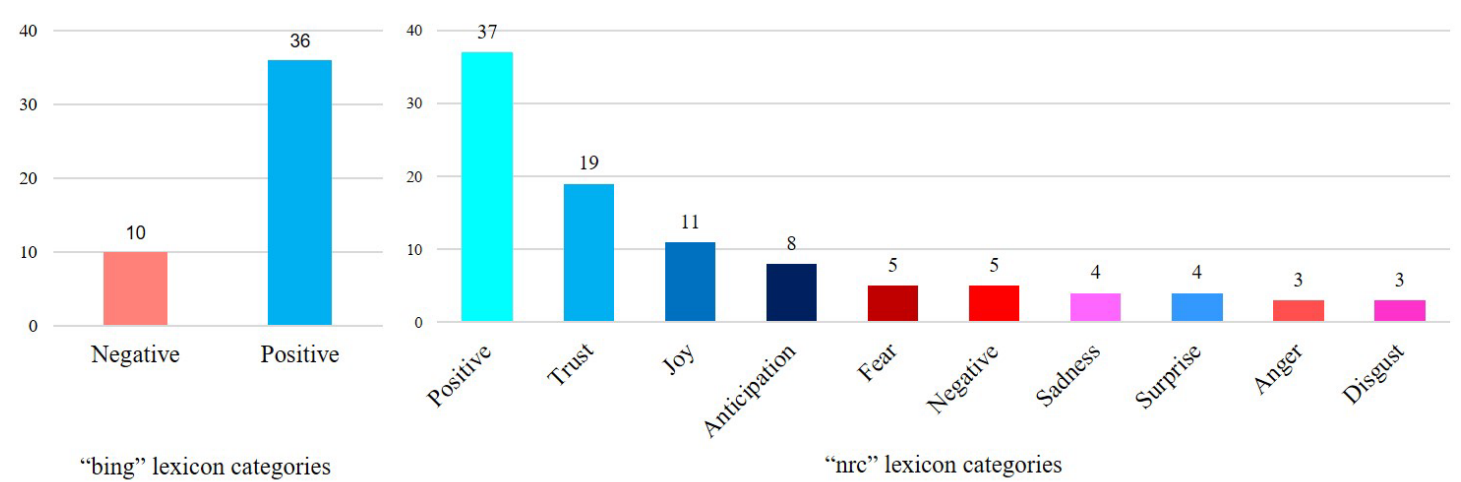


Finally, in our survey we asked quantitative questions about student's experience with the op-ed writing project. Responses indicate their level of agreement with the eight statements in Table 15 on a 5 -point Likert scale $(1=$ Strongly Disagree to $5=$ Strongly Agree). The percentage of students that agree or strongly agree to each statement is shown in the far-right column of Table 15. In sum, over half of students surveyed agree that working on the op-ed as a course project helps them to learn the topics in more depth (e.g. $63 \%$ of the students agree and strongly agree that writing the op-ed improved their understanding on the research topic)

Table 15. Distribution of student responses to the project assessment survey $(n=67)$

\begin{tabular}{|c|c|c|c|c|c|c|}
\hline Item & 1 & 2 & 3 & 4 & 5 & $4+5$ \\
\hline I am satisfied with the op-ed assignment. & $1 \%$ & $3 \%$ & $31 \%$ & $49 \%$ & $15 \%$ & $64 \%$ \\
\hline $\begin{array}{l}\text { I gained valuable experience from the op-ed } \\
\text { assignment. }\end{array}$ & $1 \%$ & $10 \%$ & $30 \%$ & $43 \%$ & $15 \%$ & $58 \%$ \\
\hline $\begin{array}{l}\text { Writing the op-ed improved my understanding on } \\
\text { the research topic. }\end{array}$ & $1 \%$ & $16 \%$ & $19 \%$ & $48 \%$ & $15 \%$ & $63 \%$ \\
\hline $\begin{array}{l}\text { I think writing an op-ed is useful for retaining the } \\
\text { knowledge I learned through the research project. }\end{array}$ & $1 \%$ & $7 \%$ & $25 \%$ & $48 \%$ & $18 \%$ & $66 \%$ \\
\hline The op-ed assignment helped me to learn. & $1 \%$ & $13 \%$ & $33 \%$ & $45 \%$ & $7 \%$ & $52 \%$ \\
\hline $\begin{array}{l}\text { The op-ed assignment helped me learn more than } \\
\text { writing another course project report. }\end{array}$ & $0 \%$ & $22 \%$ & $22 \%$ & $51 \%$ & $4 \%$ & $55 \%$ \\
\hline The op-ed assignment was relevant to the course. & $6 \%$ & $7 \%$ & $19 \%$ & $40 \%$ & $27 \%$ & $67 \%$ \\
\hline $\begin{array}{l}\text { The op-ed assignment provided me with a } \\
\text { challenge. }\end{array}$ & $3 \%$ & $6 \%$ & $12 \%$ & $63 \%$ & $16 \%$ & $79 \%$ \\
\hline
\end{tabular}
Note. 5 -point Likert scale. $1=$ Strongly Disagree to $5=$ Strongly Agree.

\section{DISCUSSION}

Designed as part of an active learning research project, the op-ed writing project offered many benefits to students. It is our observation that this project helped students develop their own voice on a topic related to their profession, learned a new way of writing, practiced teamwork, and learned how to publish on a newspaper. In this section, we discuss the benefits of this project as well as how it can be further improved. 


\section{Voice}

Students expressed greatest excitement in realizing that they can also participate in the public opinion exchange through writing op-eds. The op-ed writing project, with its instructional elements, supplemented the research project by promoting an outlet for contributing student's learning to the community and society. Many students mentioned that they realized it was so easy to submit an op-ed and their own opinion can be valuable. Writing an op-ed brings students out of the typical role of receiving knowledge, enabling and empowering them to express and construct their own opinions and solutions.

\section{Learning}

Student comments on their takeaway on learning indicate that writing an op-ed enabled them to take a deeper look at the topic that they would have otherwise disregarded, and to apply the knowledge making connections between classroom knowledge and reality. These remarks are aligned with the benefits of active learning: a deeper understanding of course concepts and a positive attitude toward learning (Salemi, 2002).

\section{Novelty}

Many students expressed excitement in doing something for the first time and learning a new writing style and structure that aims to grab public attention. The difference in format, e.g. heavier focus on the opinion than on information, and the ability to use first person, were mentioned as takeaways. 


\section{Teamwork}

Learning from the interaction with peers is one of the major benefits of active learning. Thus, the research project and the op-ed writing project were designed as team tasks. The teamwork component is also intended to enhance the student's soft skills of exchanging opinions among teammates, making compromises and negotiating a common ground, and collaborating for a common goal. The instructor and TA witnessed students actively engaging in team discussions and debates through the entire course of the semester, and the resulting team presentations and op-eds were indicators of success for such goals. However, the process for the students was apparently not easy. Student comments indicated hardship in forming a single strong opinion among four individuals with diverse views. Multiple student responses explicitly suggested assigning less people to a team - teams of two instead of four or five, or even making op-ed writing an individual project.

\section{Timing}

Activities for the op-ed writing project were concentrated in the second half of the 14week semester, whereas team research presentations were spread across those 14 weeks. Thus, the disparity of timeline may cause several issues. First, student teams that finished their research presentation earlier in the semester may be detached from their topic by the time they were required to write the op-eds. Second, the grading TA must process multiple waves of overwhelming load of student manuscripts within a short period of time. Third, the resulting student manuscripts tend to be concentrated to a few news outlets, potentially biasing the editor's decision towards rejecting most of them. Introducing the op-ed writing project early in the semester and initiating each 
team's writing process after their presentation may enhance retention of student interest, avoid concentrated workload for the grader, and enhance the chance of being accepted for publication.

\section{Choice}

Teams of Section 2 had a choice between writing an op-ed and writing a 10-page research paper. All teams opted for the op-ed. When asked the primary reason for choosing the op-ed over the research paper, $87 \%$ of individual students responded that the sheer volume of a 10-page research report vs. a 700-word op-ed was the primary factor in their decision. If the intention is to provide students with real choices that promote self-initiation and autonomy, clearly communicating the true expected workload of all alternatives, along with all of the details for the task milestones, would be crucial.

\section{Social Competition, Stress, and Grading}

In previous implementations, the instructor observed that openly complementing successful first round publication in class or rewarding publications with better grades imposed unintended stress and anxiety on some students which were so far unsuccessful in publishing their op-eds. Since the op-ed writing project is considered a supplementary activity to the research project for promoting social responsibility and improving writing skills, we decided to keep the grade weight at 5\% and not to discriminate published and unpublished teams in grading. The 5\% grade was entirely dependent on the quality of the manuscript (according to the rubric), punctuality in the iterative review process and submission to newspapers, and professional conduct in interacting with the TA and editors. 


\section{Professional Benefits}

Several students from the that successfully published their op-eds on a newspaper uploaded a link to the on-line article on their LinkedIn account. Considering the characteristic of LinkedIn as a professional social networking service, publishing their op-eds on a newspaper appears to be perceived as a significant achievement.

Students sign the op-ed submissions as "Univ. of ...... students majoring in .....", and published op-eds bring publicity to the department, college, and university. Students not only take pride in educating the public on a timely business topic, but also provide exposure to the university through publishing op-eds. A department head at the college commented: “op-ed is a wonderful opportunity for students to practice their skills in writing publicly and is also very encouraging for them to speak their thoughts. It also is good for marketing the program."

\section{CONCLUSION}

This study presents the implementation of an op-ed writing project in an undergraduate SCM course, complementing a team research project on emergent SCM topics. We have found this project to be effective in teaching students how to write an op-ed, which entails learning a novel writing style for most students. We also found the project to be competent in teaching students how to publish their opinions in a newspaper, which includes the review process and interaction with journalists and newspaper editors.

We have found this project to be beneficial to our students by engaging them in the process of forming an opinion with strong grounding in the local/regional communities and participation in the public forum of policy debates and discussions. 
Many students expressed, via survey and verbal comments, their excitement in learning that they, too, can have a voice in important global issues. By offering cutting edge business technology or contemporary global supply chain perspectives to the general public, this op-ed writing project serves as a social responsibility project for students as well. Finally, the project could also offer career benefits to the students by fortifying their critical thinking capabilities and collaborative skills, making them more valuable employees.

The op-ed writing project can be improved in various ways, including providing a broader choice of topics and teaming options. Utilizing the campus Writing Center (Kovach, Miley, \& Ramos, 2012) or collaborating with a professional journalist (Poronnik \& Moni, 2006) would help streamline the review process and improve the overall quality of student manuscripts. Further, op-ed writing may be offered to students as an optional project, allowing them to work in smaller teams. 


\section{REFERENCES}

Ashenbaum, B. (2010). The twenty-minute just-in-time exercise. Decision Sciences Journal of Innovative Education, 8(1), 269-274. doi:10.1111/j.1540$\underline{4609.2009 .00255 . x}$

Bonwell, C. C., \& Eison, J. A. (1991). Active learning: Creating excitement in the classroom. . ASHE-ERIC Higher Education Reports.

Brau, R. I., Gardner, J. W., Webb, G. S., \& McDonald, J. K. (2019). Teaching plando-study-act (pdsa) in a supply chain context: A paper football in-class activity. Decision Sciences Journal of Innovative Education, 17(1), 6-32. doi: $10.1111 /$ dsji.12171

Calavita, N., \& Krumholz, N. (2003). Capturing the public interest:Using newspaper op-eds to promote planning in conservative times. Journal of Planning Education and Research, 22(4), 400-406. doi:10.1177/0739456x03022004006

Duke University. (2019). Writing effective op-eds - communicator toolkit. September 23, available at https://commskit.duke.edu/writing-media/writing-effective-opeds/. Accessed March 15, 2020.

Ellis, S. C., Goldsby, T. J., Bailey, A. M., \& Oh, J.-Y. (2014). Teaching lean six sigma within a supply chain context: The airplane supply chain simulation. Decision Sciences Journal of Innovative Education, 12(4), 287-319. doi: $10.1111 /$ dsji.12043

Erzurumlu, S. S., \& Rollag, K. (2013). Increasing student interest and engagement with business cases by turning them into consulting exercises. Decision Sciences Journal of Innovative Education, 11(4), 359-381. doi:10.1111/dsji.12019

Hall, J. C., \& Podemska-Mikluch, M. (2015). Teaching the economic way of thinking through op-eds. International Review of Economics Education, 19, 13-21. doi:https://doi.org/10.1016/j.iree.2015.05.002

Hall, T. (2013). Op-ed and you, Opinion. The New York Times. Retrieved from https://www.nytimes.com/2013/10/14/opinion/op-ed-and-you.html. Accessed March 15, 2020.

Hill, S., \& Baker, E. (2016). An active learning exercise for product design from an operations perspective. Decision Sciences Journal of Innovative Education, 14(3), 273-284. doi:10.1111/dsji.12101

Khansari, P. S., \& Coyne, L. (2018). An innovative addition to team-based-learning pedagogy to enhance teaching and learning: Students' perceptions of team exams. Curr Pharm Teach Learn, 10(1), 90-95. doi:10.1016/j.cptl.2017.09.009

Kingston, L. N., MacCartney, D., \& Miller, A. (2014). Facilitating student engagement: Social responsibility and freshmen learning communities. Teaching \& Learning Inquiry: The ISSOTL Journal, 2(1), 63-80. doi:10.2979/teachlearninqu.2.1.63 
Kock, N., Verville, J., \& Garza, V. (2007). Media naturalness and online learning: Findings supporting both the significant-and no-significant-difference perspectives. Decision Sciences Journal of Innovative Education, 5(2), 333355.

Kovach, J. V., Miley, M., \& Ramos, M. A. (2012). Using online studio groups to improve writing competency: A pilot study in a quality improvement methods course. Decision Sciences Journal of Innovative Education, 10(3), 363-387. doi:10.1111/j.1540-4609.2012.00349.x

Li, N., Marsh, V., \& Rienties, B. (2016). Modelling and managing learner satisfaction: Use of learner feedback to enhance blended and online learning experience.

Decision Sciences Journal of Innovative Education, 14(2), 216-242. doi:10.1111/dsji.12096

Michaelsen, L. K., \& Sweet, M. (2008). The essential elements of team-based learning. New directions for teaching and learning, 2008(116), 7-27.

Miles, M. B., \& Huberman, M. A. (1994). Qualitative data analysis: An expanded sourcebook: Sage.

Omang, J. (2008). Ten steps to writing an op ed.September 27, 2019 Retrieved from http://www.inims.illinois.edu/images/MemberResources/TenStepsWritingOpE d.pdf. Accessed March 15, 2020.

Özpolat, K., Chen, Y., Hales, D., Yu, D., \& Yalcin, M. G. (2014). Using contests to provide business students project-based learning in humanitarian logistics: Psaid example. Decision Sciences Journal of Innovative Education, 12(4), 269285. doi:10.1111/dsji.12044

Parmelee, D. X., \& Michaelsen, L. K. (2010). Twelve tips for doing effective teambased learning (tbl). Medical Teacher, 32(2), 118-122. doi:10.3109/01421590903548562

Prince, M. (2004). Does active learning work? A review of the research. Journal of engineering education, 93(3), 223-231.

Poronnik, P., \& Moni, R. W. (2006). The opinion editorial: Teaching physiology outside the box. Advances in Physiology Education, 30(2), 73-82. doi:10.1152/advan.00075.2005

Salemi, M. K. (2002). An illustrated case for active learning. Southern Economic Journal, 68(3), 721-731. doi:10.2307/1061730

Schneller, A. J. (2016). Writing letters to the editor to promote environmental citizenship and improve student writing. In Learner-centered teaching activities for environmental and sustainability studies (pp. 293-299): Springer. selfdeterminationtheory.org. (2018, 06.06.2018). Intrinsic motivation inventory (imi). available at http://selfdeterminationtheory.org/intrinsic-motivation-inventory/. Accessed March 15, 2020. 
Socolow, M. J. (2010). A profitable public sphere: The creation of the new york times op-ed page. Journalism \& Mass Communication Quarterly, 87(2), 281-296. doi: $10.1177 / 107769901008700204$

Stansbury, J. A., \& Earnest, D. R. (2017). Meaningful gamification in an industrial/organizational psychology course. Teaching of Psychology, 44(1), 38-45. doi:10.1177/0098628316677645

Sun, J., Flores, J., \& Tanguma, J. (2012). E-textbooks and students' learning experiences. Decision Sciences Journal of Innovative Education, 10(1), 63-77. doi:10.1111/j.1540-4609.2011.00329.x

Sweet, M., \& Michaelsen, L. K. (2012). Team-based learning in the social sciences and humanities : Group work that works to generate critical thinking and engagement (1st ed.. ed.). Sterling, Va.: Stylus Pub.

The New York Times (1970, September 21). Op. Ed. Page. The New York Times. Retrieved from https://www.nytimes.com/1970/09/21/archives/op-ed-page78167380.html. Accessed March 15, 2020.

Wentzel, K. R. (1991). Social competence at school: Relation between social responsibility and academic achievement. Review of Educational Research, 61(1), 1-24. doi:10.3102/00346543061001001

Wilson, H. (1989). The craft of qualitative analysis. Research in nursing, 452-499. Yin, R. K. (2017). Case study research and applications: Design and methods: Sage publications. 


\section{APPENDICES}

Appendix A. Op-ed Grading Rubric.

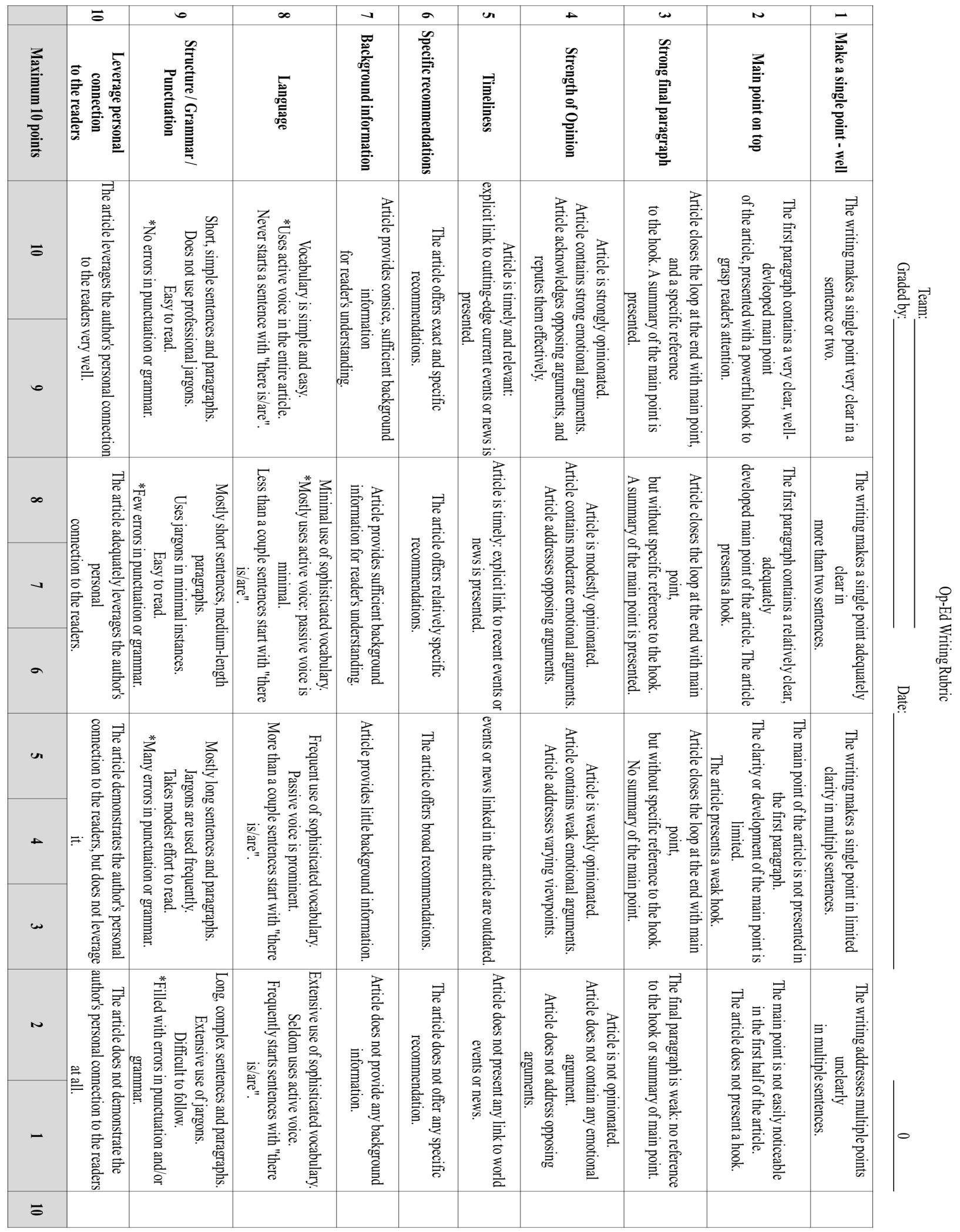




\section{Appendix B. First Draft General Feedback by TA.}

\section{Op-eds First Feedback + Second Draft Deadline + Some Tips}

Hello guys,

I replied to your submission e-mails with my feedback. Download the file, and you will see my comments on the Word document.

As I specified in the reply e-mail, please work on improving your manuscripts with your team and submit a second draft.

The deadline for the second draft submission is Wednesday, April 10, by 5:00

PM.

Many of you started your approach by extending your research presentation into writing. This resulted in many manuscripts reading like informative journalism articles, commonly found on internet news media such as VOX and Huffington Post. This is not our goal. Dedicate less space on laying out facts and information, and more on your argument, your recommendations for action on the regional, state, or national level. This also resulted on weak, or lack of, core argument. Again, this is an opinion piece, so you have to move from information to recommendation. Always think about what must be done here, in Rhode Island or the United States, and why your readers should care or be concerned.

Also, I noticed not many manuscripts employed a hard-hitting hook in the intro paragraph. This is really important, because it sets the baseline of your op-ed in the minds of the readers, and it will retain the reader through the entire article. Also, in the last paragraph, loop back to the intro hook to complete the article. An easy approach would be to look for any news on recent events or significant development, depictions 
in movies or TV, or presenting a hypothetical scenario that is rather shocking. Many other approaches may be taken, but you want your first paragraph to be impactful. When you've written your second manuscript, proofread for errors and typos before submission. I'd like to dedicate more time and energy in giving you practical guidance than in correcting writing errors.

Also, please use the file naming structure as follows: 001_Topic_Submission02.

Best,

Your TA

Appendix C. Second Draft General Feedback by TA.

Op-ed Second Draft Feedback, Final Draft Deadline, and Preparation for Newspaper Submission

Hello Class,

I was glad to see a lot of good progress.

Still, more work is needed to move on from laying down information to identifying problem areas and making calls for action with solutions.

Some common areas for improvement:

1. The first paragraph. If this is the only paragraph I read, I should still very well be able to understand your whole article. It needs to open with a hook, identify problem area, and provide the core of your solutions and suggestions. All other pertinent information can come in the following paragraphs as a supplement. Again, DO NOT wait until later in the article to present your arguments and solutions.

2. Be very specific with your suggestions and solutions. 
3. Too much information or detail hurts. Only mention necessary details briefly and move on to what YOU think should be done. Again, this is an opinion piece, not informative journalism. Any information or detail MUST have direct effect of supporting your argument and solutions.

Work with your team to improve your manuscript, and submit a third and FINAL draft by Tuesday, April 16, 5 PM. Make sure your file name is structured as follows: 01_(your topic)_Final_Draft. Editing from the feedback file would be easier.

When you submit the final draft to me, in the e-mail, state two newspapers your team would like to target for publication - make at least one of them a local newspaper. I will also provide feedback on this.

Refer to the following list:

Providence Journal: https://www.providencejournal.com/

Providence Business News: https://pbn.com/

The Call of Woonsocket: https://www.woonsocketcall.com/

Southern RI Newspapers: https://www.ricentral.com/

The Newport Daily News: https://www.newportri.com/

The Times of Pawtucket: https://www.pawtuckettimes.com/

The Westerly Sun: https://www.thewesterlysun.com/

Much more!!: https://en.wikipedia.org/wiki/List of newspapers in Rhode Island

Best,

Your TA 


\section{Appendix D. Sample Cover Letter to Editor.}

Dear Mr. Palpatine,

We'd like to submit an opinion piece on The Republic Times.

We are Coruscant native, students of the College of Business at the Jedi Academy, currently majoring in supply chain management. The goal of this piece is to explain why, as students of business, we believe Coruscant should , and to urge the state government to take action.

Having conducted research on the topic, we believe that this could serve as a major opportunity/threat for Coruscant. It could . It has the potential to

The piece is exclusive at $\underline{\mathbf{6 4 1}}$ text / $\underline{\mathbf{6 9 1}}$ with title and bio notes, and has not been submitted to or published at any other media outlet. Happy to make any needed edits.

Thank you for your consideration,

Obi-wan Kenobi and Anakin Skywalker

obi-kenobi@jedi.rep, 222-111-2211, [home address]

thechosenone@jediacademy.rep, 111-222-4433, [home address]

[op-ed attached]

\section{Appendix E. Instructions for Newspaper Submission by TA.}

\section{Instructions for Submitting Your Op-ed to Editor}

Hello Class,

Great job in advancing your op-ed articles. I was happy to see many teams develop solid op-ed articles fit for publication. 
Now that your manuscript should be ready, it's time to send it out to the newspaper editor. Closely observe the following instructions and use it as a checklist.

\section{The Op-ed Manuscript.}

Your op-ed manuscript Word document must contain ONLY the op-ed article: title, author names, main body, and bio note.

DO NOT include the cover letter, any date, course number, professor name, or edition.

Also, make sure to remove any comments and markup. Go to File-Info-Check for Issues-Inspect Document to identify anything you missed.

\section{The Target Newspaper.}

Submit to the newspaper with wider coverage first: national-regional-state-localschool.

Both Providence Journal and Providence Business News are state-level papers. If you are targeting these two papers, consider picking one for the first submission, and in case it doesn't get published, target a local paper for the second submission. You may change your target for the second submission from the paper you indicated to me. In such case, consult me via e-mail.

\section{The Cover Letter to Editor.}

Research the name of the editor of your target newspaper and direct the cover letter to $\operatorname{him} /$ her.

Formally address the editor by their last name or full name: Dear Mr. Stark, or Mrs. Mary Poppins. Don't say "Dear Tony Stark". 
Pay attention to the word count. exclusive count is for only the main body of the article. the second count is for the whole document, including title and bio notes.

\section{The submission E-mail.}

Your submission to the editor will be an e-mail, containing your cover letter and the manuscript.

Your cover letter will be the body of the e-mail. Attach your manuscript as attachment.

Should you choose to paste your op-ed in the e-mail, you should indicate by saying [Op-ed pasted and attached] at the end of the cover letter, instead of just [Op-ed attached].

It's up to you whether to just attach or paste and attach your manuscript.

[CRITICALLY IMPORTANT] BCC my email in the recipient of the e-mail. DO NOT CC or include me as a main recipient.

This will be your submission proof to me.

\section{The Submission Deadline.}

Prepare according to the above instructions and send the e-mail to the editor by no later than 5PM on Thursday, April 18.

\section{What to Do If Accepted.}

In the case your manuscript is accepted for publication, forward the e-mail from the editor to me. Although publication is not a basis for your assessment, we will still celebrate.

May the Force be with you.

Your TA 


\section{Appendix F. List of Published Student Op-eds.}

Self-driving trucks are coming. Providence Business News

Do you want to have to rely on a death to save your life? The Westerly Sun.

The blockchain could be a key cog in election reform efforts. The Westerly Sun .

A new NAFTA is being built, and we want big changes. The Westerly Sun.

We need reshoring, retraining programs. The Pawtucket Times.

Trade agreement deserves a second look. The Independent.

The Changing Arctic Sea Route and its New Opportunities. Seaview. 